\title{
Moderate Consumption of Beer and Its Effects on Cardiovascular and Metabolic Health: An Updated Review of Recent Scientific Evidence
}

\author{
Ascensión Marcos ${ }^{1, *}$, Lluís Serra-Majem ${ }^{2,3} \mathbb{D}$, Francisco Pérez-Jiménez ${ }^{2,4}$, Vicente Pascual ${ }^{5}$, \\ Francisco José Tinahones ${ }^{2,6}$ and Ramón Estruch ${ }^{2,7}$ (D)
}

check for updates

Citation: Marcos, A.; Serra-Majem, L.; Pérez-Jiménez, F.; Pascual, V.; Tinahones, F.J.; Estruch, R. Moderate Consumption of Beer and Its Effects on Cardiovascular and Metabolic Health: An Updated Review of Recent Scientific Evidence. Nutrients 2021, 13, 879. https://doi.org/ $10.3390 /$ nu13030879

Academic Editor: Ana Baylin

Received: 15 January 2021

Accepted: 3 March 2021

Published: 9 March 2021

Publisher's Note: MDPI stays neutral with regard to jurisdictional claims in published maps and institutional affiliations.

Copyright: (c) 2021 by the authors. Licensee MDPI, Basel, Switzerland. This article is an open access article distributed under the terms and conditions of the Creative Commons Attribution (CC BY) license (https:// creativecommons.org/licenses/by/ $4.0 /)$.
1 Institute of Food Science, Technology and Nutrition (ICTAN), Spanish National Research Council (CSIC), 28040 Madrid, Spain

2 CIBER Physiopathology of Obesity and Nutrition, Carlos III Institute of Health, 28222 Madrid, Spain; lluis.serra@ulpgc.es (L.S.-M.); md1pejif@uco.es (F.P.-J.); fjtinahones@hotmail.com (F.J.T.); restruch@clinic.cat (R.E.)

3 Research Institute of Biomedical and Health Sciences, University of Las Palmas de Gran Canaria, 35016 Las Palmas, Spain

4 Lipid and Atherosclerosis Unit, Maimonides Biomedical Research Institute of Córdoba (IMIBIC), UGC of Internal Medicine, Reina Sofia University Hospital, University of Córdoba, 14004 Córdoba, Spain

5 Palleter Health Centre, CEU University-Cardenal Herrera, 12005 Castellón, Spain; pascual_vic@gva.es

6 Endocrinology, Nutrition, Diabetes and Obesity Unit, Institute of Biomedical Research in Málaga (IBIMA), Virgen de la Victoria Hospital, University of Málaga, 29010 Málaga, Spain

7 Department of Internal Medicine, Hospital Clinic, August Pi i Sunyer Biomedical Research Institute (IDIBAPS), University of Barcelona, 08036 Barcelona, Spain

* Correspondence: amarcos@ictan.csic.es

\begin{abstract}
There is growing interest in the potential health-related effects of moderate alcohol consumption and, specifically, of beer. This review provides an assessment of beer-associated effects on cardiovascular and metabolic risk factors to identify a consumption level that can be considered "moderate". We identified all prospective clinical studies and systematic reviews that evaluated the health effects of beer published between January 2007 and April 2020. Five of six selected studies found a protective effect of moderate alcohol drinking on cardiovascular disease (beer up to $385 \mathrm{~g}$ /week) vs. abstainers or occasional drinkers. Four out of five papers showed an association between moderate alcohol consumption (beer intake of $84 \mathrm{~g}$ alcohol/week) and decreased mortality risk. We concluded that moderate beer consumption of up to $16 \mathrm{~g}$ alcohol/day (1 drink/day) for women and $28 \mathrm{~g} /$ day (1-2 drinks/day) for men is associated with decreased incidence of cardiovascular disease and overall mortality, among other metabolic health benefits.
\end{abstract}

Keywords: alcohol; moderate drinking; mortality; diabetes; obesity; osteoporosis

\section{Introduction}

In recent years, there has been an increasing interest in the potential health-related effects of moderate alcohol consumption. Although the harmful effects of excessive alcohol use are well established, the association of low-to-moderate alcohol consumption with health-related benefits is still controversial, since the results of available studies are not homogeneous and reaching clear conclusions is challenging. This lack of consensus is observed in alcohol consumption guidelines published in the last five years, which use different terminology ("risky drinking", "moderate consumption", or "low-risk drinking") as well as different drinking thresholds [1-6] (Table 1). Furthermore, other variables, such as differences in concentrations of non-alcoholic components (i.e., polyphenols), may confound the beneficial effects of specific alcoholic drinks $[7,8]$. 
Table 1. Low-risk drinking guidelines.

\begin{tabular}{|c|c|c|c|c|}
\hline $\begin{array}{l}\text { Country. Year } \\
\text { Guidelines }\end{array}$ & $1 \mathrm{SDU}=\mathrm{g}$ Pure Alcohol & Term & Daily $^{\mathrm{a}, \mathrm{b}}$ (g Alcohol) & Weekly $^{\mathrm{a}, \mathrm{b}}$ (g Alcohol) \\
\hline $\begin{array}{l}\text { Spain. } 2016 \\
\text { Socidrogalcohol consensus on } \\
\text { alcohol in Primary Care [2] }\end{array}$ & $\begin{array}{c}1 \text { SDU }=10 \mathrm{~g} \\
\text { Wine: } 1 \text { glass } \\
\text { Beer: } 1 \text { beer }(\approx 200 \mathrm{~mL}) \\
\text { Spirits: } 25 \mathrm{~g}\end{array}$ & $\begin{array}{l}\text { Risky consumption } \\
\text { (starting at) }\end{array}$ & $\begin{array}{l}\text { Women: } 20 \mathrm{~g} \\
\text { Men: } 40-60 \mathrm{~g}\end{array}$ & $\begin{array}{l}\text { Women: } 140 \mathrm{~g} \\
\text { Men: } 280 \mathrm{~g}\end{array}$ \\
\hline $\begin{array}{l}\text { Spain. } 2019 \\
\text { Update Dietary Guidelines for } \\
\text { the Spanish population [3] }\end{array}$ & $1 \mathrm{SDU}=10 \mathrm{~g}$ & $\begin{array}{l}\text { Moderate consumption } \\
\text { (upper limit) }\end{array}$ & $\begin{array}{c}\text { Women: }<20 \mathrm{~g} \\
\text { Men: }<40 \mathrm{~g}\end{array}$ & - \\
\hline $\begin{array}{l}\text { UK. } 2016 \\
\text { UK Chief Medical Officers' Low } \\
\text { Risk Drinking Guidelines [4] }\end{array}$ & $\begin{array}{c}1 \mathrm{SDU}=8 \mathrm{~g} \\
\text { Wine: } 1 \text { glass }(125 \mathrm{~mL}) \\
(11 \% \mathrm{ABV})\end{array}$ & $\begin{array}{l}\text { Low-risk drinking (upper } \\
\text { limit) }\end{array}$ & - & $\begin{array}{l}\text { Women: } 112 \mathrm{~g} \\
\text { Men: } 112 \mathrm{~g}\end{array}$ \\
\hline $\begin{array}{c}\text { USA. } 2015 \\
\text { Dietary guidelines [5] }\end{array}$ & $\begin{array}{c}1 \mathrm{SDU}=14 \mathrm{~g} \\
\text { Wine: } 5 \mathrm{fl} \mathrm{oz} \text { or } 147.9 \mathrm{~mL} \\
(12 \% \text { ABV }) \\
\text { Beer: } 12 \mathrm{fl} \mathrm{oz} \text { or } 354.9 \mathrm{~mL} \\
(5 \% \text { ABV }) \\
\text { Spirits: } 1.5 \mathrm{fl} \text { oz or } 44.4 \mathrm{~mL} \\
(40 \% \text { ABV })\end{array}$ & $\begin{array}{l}\text { Moderate drinking (upper } \\
\text { limit) }\end{array}$ & $\begin{array}{l}\text { Women: } 14 \mathrm{~g} \\
\text { Men: } 28 \mathrm{~g}\end{array}$ & - \\
\hline $\begin{array}{c}\text { Canada. } 2018 \\
\text { Canada low-risk alcohol } \\
\text { drinking guidelines [6] }\end{array}$ & $\begin{array}{c}1 \mathrm{SDU}^{\mathrm{c}} \approx 13 \mathrm{~g} \\
\text { Wine: } 142 \mathrm{~mL}(12 \% \mathrm{ABV}) \\
\text { Beer: } 341 \mathrm{~mL}(5 \% \mathrm{ABV}) \\
\text { Spirits: } 43 \mathrm{~mL}(40 \% \mathrm{ABV})\end{array}$ & Recommended limit & - & $\begin{array}{l}\text { Women: } 130 \mathrm{~g} \\
\text { Men: } 210 \mathrm{~g}\end{array}$ \\
\hline 37 countries. 2016 [1] & $1 \mathrm{SDU}=8-20 \mathrm{~g}$ & $\begin{array}{l}\text { Low-risk drinking (upper } \\
\text { limits range) }\end{array}$ & $\begin{array}{l}\text { Women: } 10-42 \mathrm{~g} \\
\text { Men: } 10-56 \mathrm{~g}\end{array}$ & $\begin{array}{l}\text { Women: } 98-140 \mathrm{~g} \\
\text { Men: } 150-280 \mathrm{~g}\end{array}$ \\
\hline
\end{tabular}

ABV: Alcohol by volume; SDU: Standard drinking unit. ${ }^{a}$ When amounts were expressed in number of SDUs, they were converted to grams. ${ }^{b}$ Daily and weekly values are listed as published in respective guidelines. Weekly values may not reflect a week's worth (7 days) of daily allowance. ${ }^{\mathrm{c}} 13 \mathrm{~g}$ is inferred from the different beverages considered as $1 \mathrm{SDU}$.

Beer is an alcoholic beverage frequently consumed in Europe. In 2018, the average yearly beer consumption in Europe was $72 \mathrm{~L}$ per capita, with a few countries (Czech Republic, Austria, and Germany) consuming more than 100 L per capita per year [9]. However, patterns of consumption differ across the region varying from predominantly meal-associated drinking in Mediterranean countries, to high rates of heavy episodic drinking in Central and Eastern Europe, and relatively frequent consumption both with and outside of meals in Central Western Europe [10].

Beer is mainly composed of water, but it is also rich in nutrients-carbohydrates, amino acids, minerals, vitamins, and polyphenols-resulting from a multi-step brewing and fermentation process [7,11-13]. Hop flowers, used as a bittering and flavoring agent [14], contain phenolic compounds, including prenylated flavonoids [15,16], which have been shown in vitro to have different antioxidant, anticarcinogenic, anti-inflammatory, oestrogenic, and antiviral biological activities [7,17]. Xanthohumol is the most abundant of these compounds and, in addition to potential bioactivity $[7,18]$, it also inhibits platelet activation without increasing the bleeding risk [19]. Thus, brewing processes have been optimized to achieve the highest possible content of xanthohumol [20]. Regarding antioxidant content, ale beers have been reported to display a higher antioxidant activity than lager beers due to the higher fermentation temperature in the brewing process. However, despite these enrichment processes, controversy remains as to the bioavailability of the phenolic compounds in beer [21-23].

Alcohol content in regular beers varies between 3\% and $6 \%$ alcohol by volume [11]. There is vast scientific literature on excessive alcohol consumption. Indeed, chronically high alcohol intake acts as a toxin to the heart and vascular system and may also exacerbate pre-existing heart disorders. However, low-to-moderate amounts of alcohol intake might have beneficial effects on the cardiovascular (CV) system, since it increases high-density lipoprotein cholesterol (HDL) and reduces arterial stiffness (both effects shown specifically with beer) $[21,22,24,25]$, and also decreases fibrinogen, platelet activation and aggregation, as well as blood oxidative stress and inflammatory parameters [26-28]. The alcohol content of beer might also have an effect on glucose homeostasis [29]. Alcohol contributes to total calorie intake and may increase weight when consumed in excess [30,31]. Non-alcoholic 
components also contribute to the energy content of beer. Thus, Public Health England lists the mean energy content of alcohol-free beers at seven kilocalories/100 g [32]. Overall, $28 \%$ of the total monthly kilocalories contributed by beer among regular drinkers derive from its non-alcoholic ingredients [33].

Taken together, the biological activity of phenolic compounds in beer and the possible association of alcohol intake with mortality, CV risk [34-36], and glucose metabolism [37-43] may contribute to the putative health-related effects of moderate beer consumption. Conversely, excess beer consumption may be associated with weight increase and associated morbidities [30].

We conducted an analysis of all reviews, meta-analyses, and longitudinal, prospective, cohort studies published from January 2007 to April 2020 regarding beer consumption and its relationship with CVD and mortality risk, with the objective of evaluating the average intake of beer that could be considered "moderate" based on the reported consumption. Furthermore, we aimed to identify several differences shown in specific population subgroups in the selected studies.

\section{Materials and Methods}

In April 2020, a literature search of papers published after January 2007 was conducted using PubMed EMBASE, and through reference list cross-checking of previous meta-analyses, prospective clinical studies, and systematic reviews in humans, evaluating beer effects on health. The search strategy retrieved citations from databases containing the subject heading "beer" in combination with "health", "cardiovascular", "mortality", "obesity", "diabetes", "young", "women", or "alcoholism". The search terms were adapted for use with both bibliographic databases (Table 2).

Table 2. Literature search terms.

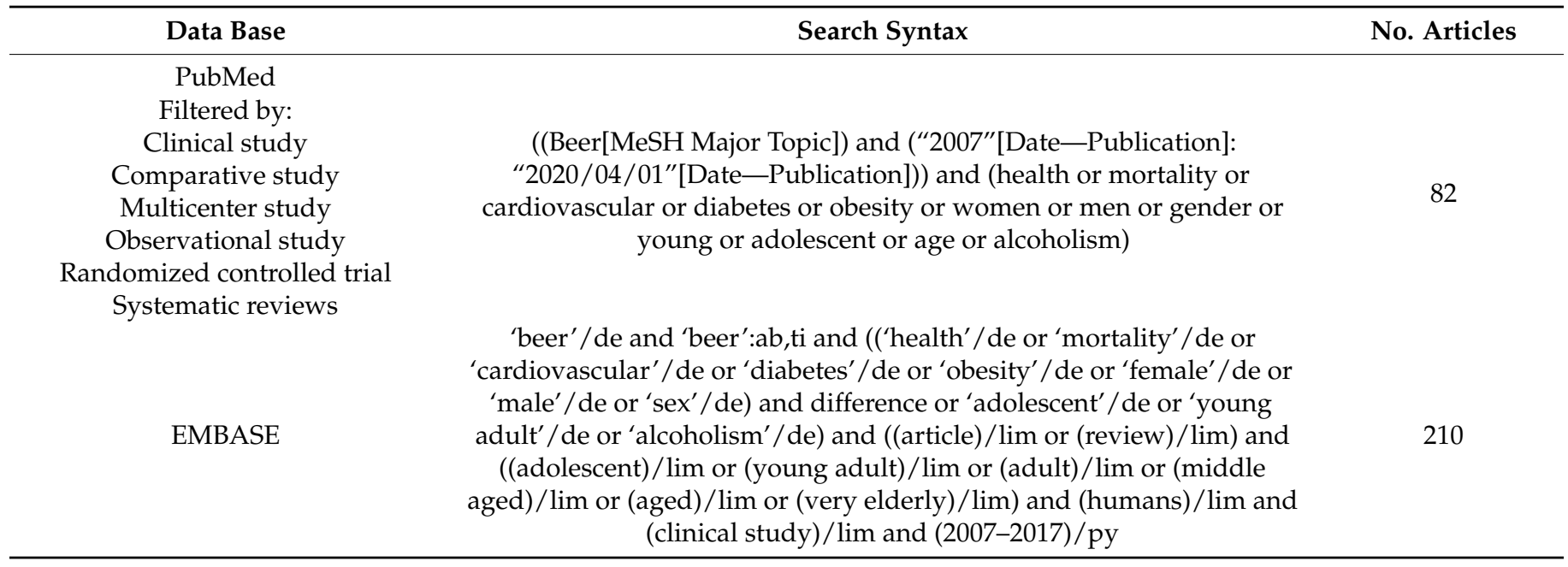

Original eligible papers, based on their title/abstract, were obtained and reviewed to select those meeting the inclusion criteria: clinical studies in humans with prospective cohort design, plus systematic reviews and meta-analyses evaluating beer effects on health since 2007, and publications that authors considered could provide additional information on the subject. A total of 13 reviews (narrative or systematic reviews and/or meta-analysis), 9 prospective cohort studies, and 1 open-label, randomized, cross-over study were selected (Table 3). 
Table 3. Papers selected for review.

\begin{tabular}{|c|c|c|}
\hline Alcohol/Beer Paper & Study Type & Related Subject \\
\hline Osorio-Paz et al. 2019 [44] & Review & $\mathrm{CV}$ \\
\hline Sacanella et al. Nutr Hosp. 2019 [22] & Review & $\mathrm{CV}$ \\
\hline Humia et al. Molecules 2019 [21] & Review & $\mathrm{CV}$ \\
\hline Redondo et al. Nutr Hosp 2018 [45] & Review & $\mathrm{CV}$ and osteoporosis \\
\hline Padro et al. Nutrients 2018 [46] & Prospective randomized cross-over & Obesity (metabolic syndrome) \\
\hline Wood et al. Lancet. 2018 [47] & System. Review/Meta & CV and Mortality \\
\hline Toma et al. Curr Atheroscler Rep. 2017 [48] & Review & $\mathrm{CV}$ \\
\hline Bell et al. BMJ 2017 [49] & Prospective cohort & $\mathrm{CV}$ \\
\hline Polsky et al. Curr Diab Rep. 2017 [50] & System. Review & Diabetes \\
\hline Xi et al. J Am Coll Cardiol. 2017 [51] & Prospective population-based cohort & Mortality \\
\hline $\begin{array}{l}\text { de Gaetano et al. Nutr Metab Cardiovasc Dis. } \\
\qquad 2016 \text { [34] }\end{array}$ & Review & CV and Mortality \\
\hline Fresán et al. Nutrients. 2016 [52] & Prospective cohort & Obesity \\
\hline Stockwell et al. J. Stud. Alcohol Drugs. 2016 [53] & System. Review/Meta & Mortality \\
\hline Roerecke et al. BMC Med. 2014 [54] & System. Review/Meta & $\mathrm{CV}$ \\
\hline Bendsen et al. Nutr Rev. 2013 [55] & System. Review / Meta & Obesity \\
\hline Cullmann et al. Diabetic Medicine. 2012 [43] & Prospective cohort & Diabetes \\
\hline Roerecke et al. Addiction. 2012 [56] & System. Review/Meta & $\mathrm{CV}$ \\
\hline Costanzo S, et al. Eur J Epidemiol. 2011 [57] & System. Review/Meta & $\mathrm{CV}$ \\
\hline Yin et al. Eur J Clin Nutr. 2011 [58] & Prospective cohort & Osteoporosis \\
\hline Schütze et al. Eur J Clin Nutr 2009 [59] & Prospective cohort & Obesity \\
\hline Snow et al. Age and Ageing. 2009 [60] & Prospective cohort & CV and Mortality \\
\hline Suadicani et al. Alcohol. 2008 [61] & Prospective cohort & Mortality \\
\hline Mukamal et al. Osteoporos Int. 2007 [62] & Prospective population-based cohort & Osteoporosis \\
\hline
\end{tabular}

CV. Cardiovascular.

\section{Results}

A summary of related studies is shown in Table 4 . Two reviews referring specifically to beer, reported that moderate consumption (up to $55 \mathrm{~g}$ alcohol/day; i.e., $385 \mathrm{~g} /$ week) showed a beneficial effect on non-fatal CV events [34,57]. Both reviews found that the highest effect was associated with moderate beer or wine consumption, suggesting that the polyphenolic content of these beverages probably contributes to the observed $\mathrm{CV}$ benefits $[34,57]$. 
Table 4. Summary of the main cardiovascular (CV) studies.

\begin{tabular}{|c|c|c|c|c|c|c|}
\hline $\begin{array}{c}\text { Study } \\
\text { Funding/COI }\end{array}$ & $\begin{array}{l}\text { Design (Mean/Median } \\
\text { Years of Follow-Up) }\end{array}$ & $n$ & $\begin{array}{c}\text { Categories of } \\
\text { Consumption/Type of } \\
\text { Drink }\end{array}$ & Variables & $\begin{array}{c}\text { Reference } \\
\text { Group }(\mathrm{HR}=1)\end{array}$ & Outcomes/Conclusions ${ }^{b}$ \\
\hline $\begin{array}{c}\text { Costanzo et al., } 2011 \text { [57] } \\
\text { Cervisia Consulenze } \\
\text { and } \\
\text { Istituto Nazionale per la } \\
\text { Comunicazione. }\end{array}$ & $\begin{array}{c}\text { Systematic } \\
\text { review-meta-analysis }\end{array}$ & $\begin{array}{l}12 \text { prospective studies ( } \\
\text { ranged from } 1373 \text { to } \\
87,536) \text { and } 6 \\
\text { case-control studies ( } n \\
\text { ranged from } 616 \text { to } 1746)\end{array}$ & Wine, beer, and spirits & $\begin{array}{l}\text { Fatal non-fatal CHD, } \\
\text { CHD, CVD, AMI, stroke, } \\
\text { CHD mortality, IHD } \\
\text { mortality, CVD mortality } \\
\text { AND/OR total mortality. }\end{array}$ & & $\begin{array}{c}13 \text { studies: J-shaped relationship } \\
\text { for beer and CV risk. } \\
16 \text { studies: J-shaped relationship } \\
\text { between wine intake and CV } \\
\text { risk. } 12 \text { studies reporting } \\
\text { separate data on wine or beer } \\
\text { consumption: two closely } \\
\text { overlapping dose-response } \\
\text { curves. }\end{array}$ \\
\hline $\begin{array}{l}\text { Roerecke et al., } 2012 \text { [56] } \\
\text { Global Burden of } \\
\text { Disease Study and } \\
\text { by the grant “Drinking } \\
\text { Patterns \& Ethnicity: } \\
\text { Impact on Mortality } \\
\text { Risks", NIAAA }\end{array}$ & $\begin{array}{c}\text { Systematic } \\
\text { review-meta-analysis }\end{array}$ & $\begin{array}{l}44 \text { observational studies } \\
\text { including } 957,684 \\
\text { participants }\end{array}$ & $\begin{array}{l}\text { Lifetime abstainer. } \\
\text { Occasional: } \\
\text { 2.5-11.99 g/week; } \\
\text { 12-23.99 g/week; } \\
\text { 24-35.99 g/week } \\
\text { Alcohol in general }\end{array}$ & IHD & $\begin{array}{l}\text { Lifetime } \\
\text { abstainers }\end{array}$ & $\begin{array}{l}\text { Cardioprotection was observed } \\
\text { in all strata, and substantial } \\
\text { heterogeneity was noted across } \\
\text { studies. Wide confidence } \\
\text { intervals observed particularly } \\
\text { for average consumption of } \\
\text { 1-2 drinks per day. }\end{array}$ \\
\hline $\begin{array}{l}\text { Roerecke et al., } 2014 \text { [54] } \\
\text { The European } \\
\text { Community's Seventh } \\
\text { Framework } \\
\text { Programme-- } \\
\text { Addictions and Lifestyle } \\
\text { in Contemporary } \\
\text { Europe-Reframing } \\
\text { Addictions Project. }\end{array}$ & $\begin{array}{l}\text { Systematic review and } \\
\text { meta-analysis }\end{array}$ & $\begin{array}{l}7 \text { studies for the } \\
\text { meta-analysis }\end{array}$ & $\begin{array}{c}\text { For the meta-analysis: } \\
\text { Current drinkers with an } \\
\text { average alcohol } \\
\text { consumption }<30 \mathrm{~g} / \text { day } \\
\text { of pure alcohol with or } \\
\text { without HED } \\
\text { Alcohol in general }\end{array}$ & IHD & $\begin{array}{l}\text { Lifetime } \\
\text { abstainers }\end{array}$ & $\begin{array}{l}\text { Beneficial effect of low alcohol } \\
\text { consumption without HED } \\
\text { episodes as compared to } \\
\text { life-time abstainers }\end{array}$ \\
\hline $\begin{array}{l}\text { Wood et al., } 2018 \text { [47] } \\
\text { Various government, } \\
\text { private, and } \\
\text { pharmaceutical sources. } \\
\text { / None declared. }\end{array}$ & $\begin{array}{l}\text { Systematic review and } \\
\text { meta-analysis }\end{array}$ & $\begin{array}{c}83 \text { prospective studies } \\
\text { including } 599,912 \\
\text { participants }\end{array}$ & $\begin{array}{c}\text { Current drinkers } \\
\text { / } \\
\text { Alcohol in general, also } \\
\text { separate analyses for } \\
\text { wine, beer, and spirits }\end{array}$ & $\begin{array}{l}\text { Mortality, stroke, CHD, } \\
\text { AMI, heart failure, fatal } \\
\text { hypertensive disease, } \\
\text { fatal aortic aneurysm }\end{array}$ & $\begin{array}{l}\text { Lowest baseline } \\
\text { alcohol } \\
\text { consumption } \\
\text { category } \\
\text { (0-25 g/week) }\end{array}$ & $\begin{array}{l}\text { Threshold for lowest risk of } \\
\text { all-cause mortality was } \\
\sim 100 \mathrm{~g} / \text { week. Association } \\
\text { between alcohol consumption } \\
\text { and total CVD risk showed } \\
\text { higher HR for beer and spirits } \\
\text { than for wine. }\end{array}$ \\
\hline
\end{tabular}


Table 4. Cont.

\begin{tabular}{|c|c|c|c|c|c|c|}
\hline $\begin{array}{c}\text { Study } \\
\text { Funding/COI }\end{array}$ & $\begin{array}{l}\text { Design (Mean/Median } \\
\text { Years of Follow-Up) }\end{array}$ & $n$ & $\begin{array}{c}\text { Categories of } \\
\text { Consumption/Type of } \\
\text { Drink }\end{array}$ & Variables & $\begin{array}{c}\text { Reference } \\
\text { Group }(\mathrm{HR}=1)\end{array}$ & Outcomes/Conclusions ${ }^{b}$ \\
\hline $\begin{array}{l}\text { de Gaetano et al., } 2016 \\
\text { [34] } \\
\text { Assobirra, the } \\
\text { Italian Association of the } \\
\text { Beer and Malt } \\
\text { Industries/Some authors } \\
\text { were consultants for the } \\
\text { Web Newsletter } \\
\text { of Assobirra, or were } \\
\text { on the board/received } \\
\text { lecture fees from FIVIN, } \\
\text { the Beer and } \\
\text { Health Foundation, } \\
\text { ERAB, or Cerveceros } \\
\text { de España. }\end{array}$ & Systematic review & $\begin{array}{l}7 \text { prospective studies } \\
\text { (n ranged from } 1373 \text { to } \\
87,526) \text { and } 4 \\
\text { case-control studies ( } \\
\text { ranged from } 937 \text { to } \\
1514)\end{array}$ & Wine, beer, and spirits & $\begin{array}{l}\text { Fatal non-fatal CHD, } \\
\text { AMI, CHD, CHD } \\
\text { mortality, AND/OR } \\
\text { CVD mortality. }\end{array}$ & & Some benefit of beer against CVD \\
\hline
\end{tabular}


Table 4. Cont.

\begin{tabular}{|c|c|c|c|c|c|c|}
\hline $\begin{array}{c}\text { Study } \\
\text { Funding/COI }\end{array}$ & $\begin{array}{l}\text { Design (Mean/Median } \\
\text { Years of Follow-Up) }\end{array}$ & $n$ & $\begin{array}{c}\text { Categories of } \\
\text { Consumption/Type of } \\
\text { Drink }\end{array}$ & Variables & $\begin{array}{c}\text { Reference } \\
\text { Group }(\mathrm{HR}=1)\end{array}$ & Outcomes/Conclusions ${ }^{b}$ \\
\hline $\begin{array}{c}\text { Bell et al., } 2017 \text { [49] } \\
\text { National Institute for } \\
\text { Health Research, } \\
\text { Welcome Trust, the } \\
\text { Medical Research } \\
\text { Council prognosis } \\
\text { research strategy } \\
\text { Partnership and other } \\
\text { government } \\
\text { health-related agencies. / } \\
\text { None declared }\end{array}$ & $\begin{array}{l}\text { Prospective cohort } \\
\text { (6 y) }\end{array}$ & $1,937,360$ (51\% women) & $\begin{array}{l}\text { Non-drinkers. Former } \\
\text { drinkers. Occasional } \\
\text { drinkers: drinks rarely or } \\
\text { occasionally. Moderate: } \\
\text { Men: } 21 \text { SDU / week or } 3 \\
\text { SDU/day. Women: } 14 \\
\text { SDU/w or } 2 \text { SDU/da. } \\
\text { Heavy drinkers } \\
\text { / } \\
\text { Alcohol in general }\end{array}$ & $\begin{array}{l}12 \text { common symptomatic } \\
\text { manifestations of CVD. } \\
\text { Aggregated CVD (all CV } \\
\text { endpoints other than } \\
\text { stable angina). }\end{array}$ & $\begin{array}{l}\text { Moderate } \\
\text { drinkers }\end{array}$ & 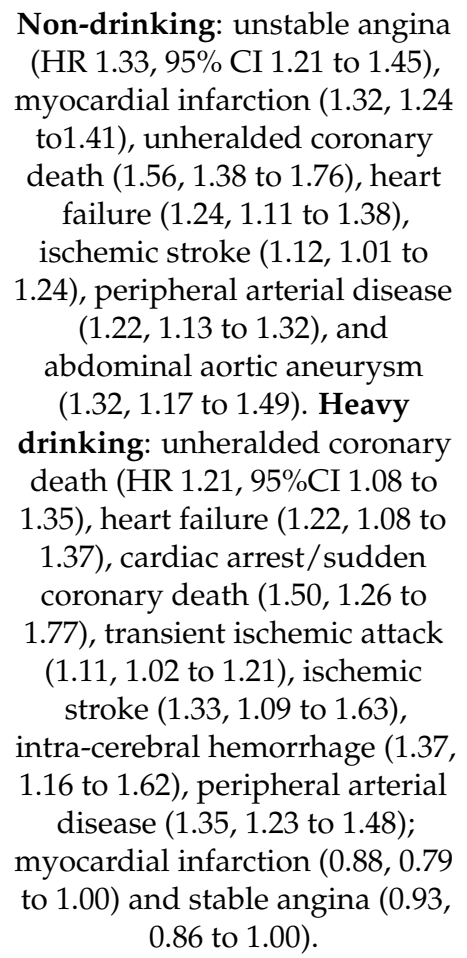 \\
\hline
\end{tabular}


Table 4. Cont.

\begin{tabular}{|c|c|c|c|c|c|c|}
\hline $\begin{array}{c}\text { Study } \\
\text { Funding/COI }\end{array}$ & $\begin{array}{l}\text { Design (Mean/Median } \\
\text { Years of Follow-Up) }\end{array}$ & $n$ & $\begin{array}{c}\text { Categories of } \\
\text { Consumption/Type of } \\
\text { Drink }\end{array}$ & Variables & $\begin{array}{c}\text { Reference } \\
\text { Group (HR = 1) }\end{array}$ & Outcomes/Conclusions ${ }^{b}$ \\
\hline $\begin{array}{l}\text { Snow et al., } 2009 \text { [60] } \\
\text { None declared }\end{array}$ & $\begin{array}{l}\text { Prospective cohort } \\
\qquad(10 \mathrm{y})\end{array}$ & 1154 (574 women) & $\begin{array}{l}\text { 1 SDU: } 13 \text { g ethanol. } \\
\text { Men: Light: 0.65-5.77 } \\
\text { g/day; Moderate: } \\
\text { 5.78-18.1 g/day; Heavy: } \\
\text { >18.1 g/day. HED: } \geq 8 \\
\text { drinks/episode in past } \\
\text { year } \\
\text { Women: Light: 0.65-2.92 } \\
\text { g/day; Moderate: } \\
\text { 2.93-9.15 g/day; Heavy: } \\
\text { >9.15 g/day. HED: } \\
\text { frequency of } \geq 8 \\
\text { drinks/episode } \\
\text { / } \\
\text { Alcohol in general }\end{array}$ & $\begin{array}{l}\text { CHD events; } \\
\text { hypertension; Other } \\
\text { CVD }\end{array}$ & $\begin{array}{c}\text { Lifetime } \\
\text { abstainers and } \\
\text { occasional } \\
\text { drinkers who } \\
\text { consumed }<0.05 \\
\text { drinks }(<0.65 \mathrm{~g}) \\
\text { per day. }\end{array}$ & $\begin{array}{c}\text { Men for CHD events: Heavy: } \\
\text { HR: } 0.28 \text { (0.08-0.93) } p=0.037 \text { in } \\
\text { old men; HED: } 4.13(1.46-11.62) \\
p=0.0073 \text { in middle-aged men. } \\
\text { Men for hypertension: HED: } \\
\text { HR } 1.62(0.99-2.63), p=0.054 \text { in } \\
\text { old men. } \\
\text { Men for other CVD: Light: HR } \\
0.54 \text { (0.28-1.04), } p=0.066 \text { in old } \\
\text { men; Heavy: HR } 0.40 \\
(0.19-0.85, p=0.017 \text { in old men. } \\
\text { Women for hypertension: } \\
\text { Light: HR } 0.26(0.07-1.01), \\
p=0.052 \text { in young women. } \\
\text { Women for other CVD: Light: } \\
\text { HR } 0.23 \text { (0.08-0.65), } p=0.0057 \\
\text { and Moderate: HR } 0.14 \\
(0.05-0.45), p=0.0009 \text { in young } \\
\text { women. }\end{array}$ \\
\hline
\end{tabular}

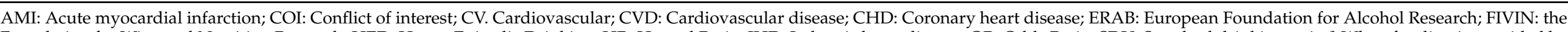

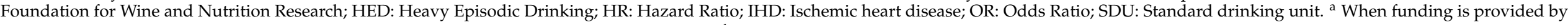

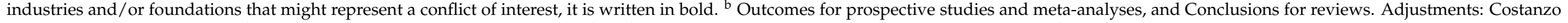

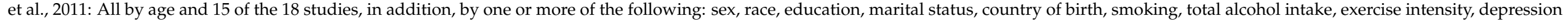

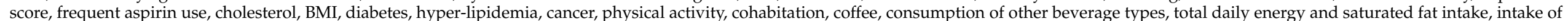

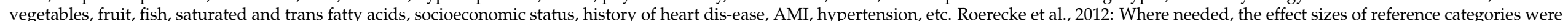

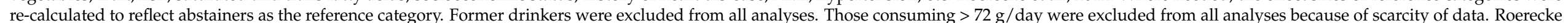

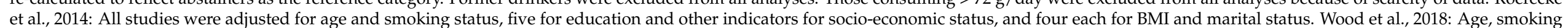

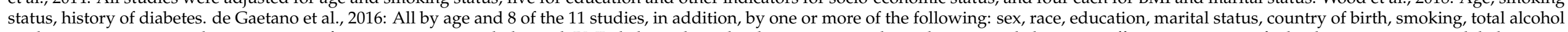

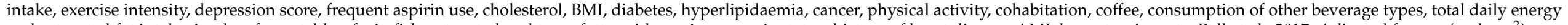

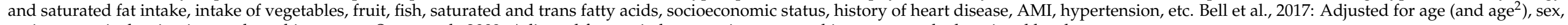
socioeconomic deprivation, and smoking status. Snow et al., 2009: Adjusted for marital status, cigarette smoking status and educational level. 
These data are in agreement with most findings from reviews/meta-analyses and cohort studies, which report a protective effect of moderate alcohol drinking for CVD compared to abstention, former drinking, or occasional drinking [22,34,47,49,56,57,60]. Only the review by Toma et al. does not support these conclusions; the authors suggest that this protective effect may be a confounder due to the inclusion of former drinkers in the non-drinkers group [48]. However, the prospective cohort study by Bell et al., conducted in almost 2 million people, took these potential confounders into consideration, and also found a positive effect of moderate drinking (112 g/week in women and $168 \mathrm{~g} /$ week in men) on CV risk [49]. Costanzo et al. found a negative (although not significant) association between spirits and vascular events, suggesting alcohol content, and not solely polyphenols, may also play a role in cardiovascular events [57]. Moreover, as Roerecke et al. [54] noted that distinctions between former drinkers and lifetime abstainers might not be sufficient for an accurate analysis, based on the heterogeneity of reasons underlying non-drinkers' decision not to drink, which might further confound the results. Finally, drinking patterns may also play a key role in outcomes [54], since self-reported weekly intakes might include alcohol consumed during the weekend during a binge, which would be associated with worse $\mathrm{CV}$ results.

\section{Gender Differences}

Due to the paucity of separate data for men and women, none of the beer-specific CVD studies stratified their conclusions by gender. The meta-analysis by Roerecke et al. [54] noted that women are more sensitive to the protective effect of moderate alcohol consumption, based on a previous meta-analysis [56], which showed a steeper J-curve for ischemic heart disease (IHD), mortality and morbidity in women than in men. The detrimental effect on CV risk of binge drinking seems to be lower in women than in men $[49,60]$, and an increased risk of heart failure has been observed in abstemious women compared with moderate drinkers [49]. In addition, Snow et al. [60] observed that the beneficial effects of low and/or moderate usual consumption on CV risk were only evident in younger women (aged 18-34), whereas cardio-protection became evident at middle (aged 35-49) or older age (aged 50-64) in men. Overall, these gender differences may be due to hormonal changes over the life course or to a lower lifetime consumption of total alcohol.

\section{Moderate Beer Consumption and Mortality}

A summary of related studies is shown in Table 5. The systematic review by de Gaetano et al. [34] suggested that a J-shaped relationship also exists between beer consumption and all-cause mortality. The lowest mortality risk was observed in subjects with low to moderate alcohol consumption compared to abstainers or heavy drinkers, with the lowest risk at beer consumption of $84 \mathrm{~g}$ alcohol/week [34]. 
Table 5. Summary of main mortality studies.

\begin{tabular}{|c|c|c|c|c|c|c|}
\hline $\begin{array}{c}\text { Study } \\
\text { Funding/COI }{ }^{a}\end{array}$ & $\begin{array}{c}\text { Design } \\
\text { (Mean/Median } \\
\text { Years of Follow-Up) }\end{array}$ & $n$ (Women) & $\begin{array}{l}\text { Categories of Alcohol } \\
\text { Consumption/Type of } \\
\text { Drink }\end{array}$ & Variable/s & $\begin{array}{c}\text { Reference } \\
\text { Group }(\mathrm{HR}=1)\end{array}$ & Outcomes/Conclusions ${ }^{b}$ \\
\hline \multirow{4}{*}{$\begin{array}{l}\text { de Gaetano et al., } \\
2016 \text { [34] } \\
\text { Assobirra, the } \\
\text { Italian Association of } \\
\text { the Beer and Malt } \\
\text { Industries/ Some } \\
\text { authors were } \\
\text { consultants for the } \\
\text { Web Newsletter } \\
\text { of Assobirra, or were } \\
\text { on the } \\
\text { board/received } \\
\text { lecture fees from } \\
\text { Fundación Cerveza y } \\
\text { Salud, FIVIN, the } \\
\text { Beer and } \\
\text { Health Foundation, } \\
\text { ERAB, or Cerveceros } \\
\text { de España. }\end{array}$} & Systematic review & & Wine, beer, and spirits & All-cause mortality & & $\begin{array}{l}\text { Evidence suggests a J-shaped } \\
\text { relationship between alcohol } \\
\text { consumption and total mortality, with } \\
\text { lower risk for moderate alcohol } \\
\text { consumers than for abstainers or heavy } \\
\text { drinkers. } \\
\text { Specific data on beer are not conclusive, } \\
\text { although some results indicate a } \\
\text { positive role of drinking beer in } \\
\text { moderation (1 drink/day, about } 12 \mathrm{~g} \text { of } \\
\text { ethanol) against mortality for any cause }\end{array}$ \\
\hline & $\begin{array}{c}1 \text { meta-analysis of } 34 \\
\text { prospective studies } \\
\text { [65] }\end{array}$ & Over 1 million adults & $\begin{array}{l}\text { Low to moderate } \\
\text { Women: } 1 \text { drink/day. } \\
\text { Men: } 2 \text { drinks/day } \\
\text { Wine, beer, and spirits }\end{array}$ & All-cause mortality & & $\begin{array}{l}\text { Low to moderate consumption of } \\
\text { alcohol significantly reduces total } \\
\text { mortality, while higher doses increase it }\end{array}$ \\
\hline & $\begin{array}{c}1 \text { Prospective cohort } \\
{[66]} \\
(12-18 \mathrm{y})\end{array}$ & 36,250 men & Wine and beer & $\begin{array}{c}\text { CV death } \\
\text { All-cause mortality }\end{array}$ & Non-drinkers & $\begin{array}{l}\text { Moderate wine or beer drinking } \\
\text { reduced the risk of } C V \text { death. } \\
\text { Only moderate wine drinking was } \\
\text { associated with lower all-cause } \\
\text { mortality: RR: } 0.67(0.58 \text { to } 0.77 \text {; } \\
\quad p<0.001)\end{array}$ \\
\hline & $\begin{array}{c}1 \text { Prospective cohort } \\
{[67]} \\
(16.8 \mathrm{y})\end{array}$ & $\begin{array}{l}7735 \text { British men } 40-59 \text { y } \\
\text { old }\end{array}$ & $\begin{array}{l}1 \text { SDU: Half pint beer } \\
\text { (8-10 g alcohol). } \\
\text { Frequency: } \\
\text { Non-drinkers; } \\
\text { Occasional (1-2 } \\
\text { SDU/month); Weekend } \\
\text { drinkers; Daily or on } \\
\text { most days. Quantity: } \\
\text { 1-2, 3-6, }>6 \\
/ \\
\text { Wine, beer, and spirits }\end{array}$ & All-cause mortality & $\begin{array}{l}\text { Occasional } \\
\text { drinkers }\end{array}$ & $\begin{array}{c}\text { Regular beer drinking [HR: } 0.84 \text { ( } 0.71 \text { to } \\
\text { 1.01)] showed no significant difference } \\
\text { vs. occasional drinking }\end{array}$ \\
\hline
\end{tabular}


Table 5. Cont

\begin{tabular}{|c|c|c|c|c|c|c|}
\hline $\begin{array}{c}\text { Study } \\
\text { Funding/COI }\end{array}$ & $\begin{array}{c}\text { Design } \\
\text { (Mean/Median } \\
\text { Years of Follow-Up) }\end{array}$ & $n$ (Women) & $\begin{array}{c}\text { Categories of Alcohol } \\
\text { Consumption/Type of } \\
\text { Drink }\end{array}$ & Variable/s & $\begin{array}{c}\text { Reference } \\
\text { Group }(\mathrm{HR}=1)\end{array}$ & Outcomes/Conclusions ${ }^{b}$ \\
\hline & $\begin{array}{c}1 \text { Prospective cohort } \\
\text { [68] } \\
\text { Copenhagen City } \\
\text { Heart Study (25 y) }\end{array}$ & 14,223 adults & $\begin{array}{l}\text { 1 SDU: } 1 \text { bottle beer (12 g } \\
\text { alcohol). Never, Hardly } \\
\text { ever, Monthly, Weekly } \\
\text { Daily: } 1-2 \text { SDUs } \\
\text { Daily: >2 SDUs } \\
\text { / } \\
\text { Wine, beer, and spirits }\end{array}$ & All-cause mortality & $\begin{array}{l}\text { Never beer } \\
\text { drinkers }\end{array}$ & $\begin{array}{c}\text { In men, monthly beer intake (RR: } 0.86 \\
(0.77 \text { to } 0.97) \text { ) was associated with lower } \\
\text { mortality, and daily intake }>2 \text { beers (RR: } \\
1.14 \text { (1.02 to } 1.27) \text { ) to increased risk. } \\
\text { In women the associations were not } \\
\text { statistically significant: Monthly beer } \\
\text { intake (RR: } 0.98 \text { ( } 0.88 \text { to } 1.08) \text { ), and daily } \\
\text { intake }>2 \text { beers (RR: } 1.31(0.92 \text { to } 1.88) \text { ) } \\
\text { At a medium education level, monthly } \\
\text { beer intake was associated with lower } \\
\text { risk (RR: } 0.87(0.77 \text { to } 0.97) \text { ), and at low } \\
\text { [RR:1.20 (1.07 to } 1.34) \text { and medium } \\
\text { education level (RR:1.18 (1.02 to } 1.37) \text { ), } \\
>2 \text { beers daily was associated with } \\
\text { increased risk. }\end{array}$ \\
\hline & $\begin{array}{c}1 \text { Prospective cohort } \\
{[69]} \\
(12.6 \mathrm{y})\end{array}$ & $\begin{array}{c}380,395 \text { adults }(247,795 \\
\text { women) }\end{array}$ & $\begin{array}{c}\text { For beer: } \\
\text { Never. Light: 0.1-2.9 } \\
\text { g/day, 3-9.9 g/day, } \\
\text { 10-19.9 g/day, 20-39.9 } \\
\text { g/day (only for men). } \\
\geq 20 \text { g/day (extreme for } \\
\text { women) } \\
\geq 40 \text { g/day (extreme for } \\
\text { men) } \\
/ \\
\text { Wine and beer }\end{array}$ & All-cause mortality & $\begin{array}{l}\text { Light consumers } \\
(0.1-2.9 \mathrm{~g} / \text { day })\end{array}$ & $\begin{array}{c}\text { In women: } \\
\text { Compared to low-level consumers, } \\
\text { lifetime non-drinkers (HR: } 1.06 ; 1.02 \text { to } \\
\text { 1.12), and consumers of beer at amounts } \\
\geq 3 \mathrm{~g} / \text { day displayed significantly } \\
\text { higher overall mortality risk. } \\
\text { In men: } \\
\text { Lifetime non-drinkers (HR: } 1.07 ; 0.98 \text { to } \\
\text { 1.16) and consumers of } 3-9.9 \mathrm{~g} / \text { day } \\
\text { (HR: } 1.04 ; 0.98 \text { to } 1.10 \text { ) showed no } \\
\text { significant differences compared to } \\
\text { light consumers. } \\
\text { Consumers of beer amounts } \geq 10 \text { g/day } \\
\text { displayed a significantly higher overall } \\
\text { mortality risk. }\end{array}$ \\
\hline
\end{tabular}


Table 5. Cont.

\begin{tabular}{|c|c|c|c|c|c|c|}
\hline $\begin{array}{c}\text { Study } \\
\text { Funding/COI }^{a}\end{array}$ & $\begin{array}{c}\text { Design } \\
\text { (Mean/Median } \\
\text { Years of Follow-Up) }\end{array}$ & $n$ (Women) & $\begin{array}{c}\text { Categories of Alcohol } \\
\text { Consumption/Type of } \\
\text { Drink }\end{array}$ & Variable/s & $\begin{array}{c}\text { Reference } \\
\text { Group }(\mathrm{HR}=1)\end{array}$ & Outcomes/Conclusions ${ }^{b}$ \\
\hline $\begin{array}{c}\text { Stockwell et al., } 2016 \\
\text { [53] } \\
\text { None declared }\end{array}$ & $\begin{array}{c}\text { Systematic } \\
\text { review / meta- } \\
\text { analysis of } 87 \text { studies } \\
(13.4 \mathrm{y})\end{array}$ & 3998,626 adults & $\begin{array}{c}\text { Abstainer. Former } \\
\text { drinker. Occasional: } \\
<1.30 \mathrm{~g} / \text { day. Low: } 1.30 \\
\text { to }<25 \mathrm{~g} / \text { day. Medium: } \\
25 \text { to }<45 \mathrm{~g} / \text { day } \\
\text { High: } 45 \text { to }<65 \mathrm{~g} / \text { day. } \\
\text { Higher: } \geq 65 \mathrm{~g} / \text { day } \\
\text { Alcohol in general }\end{array}$ & All-cause mortality & $\begin{array}{l}\text { Abstainer OR } \\
\text { occasional } \\
\text { drinker }\end{array}$ & $\begin{array}{c}\text { Standard adjustment: Significant } \\
\text { protective effect for low-volume (RR: } \\
0.86 \text { ( } 0.83 \text { to } 0.90) ; p<0.0001) \text { and } \\
\text { occasional drinkers (RR: } 0.84 \text { (0.79 to } \\
0.89) ; p<0.0001) \text { as compared with } \\
\text { abstainers. } \\
\text { Abstainers were at significantly higher } \\
\text { risk (RR: } 1.19 \text { (1.12 to } 1.27) ; p<0.0001) \\
\text { as compared to occasional drinkers. } \\
\text { Full adjustment: No significant } \\
\text { protection was estimated for occasional } \\
\text { (RR: } 0.95 \text { ( } 0.85 \text { to } 1.05)), \text { low-volume } \\
\text { (RR: } 0.97(0.88 \text { to } 1.07) \text { ), or } \\
\text { medium-volume drinkers (RR: } 1.07 \\
\text { (0.97 to } 1.18) \text { ) as compared with } \\
\text { abstainers. }\end{array}$ \\
\hline
\end{tabular}


Table 5. Cont.

\begin{tabular}{|c|c|c|c|c|c|c|}
\hline $\begin{array}{c}\text { Study } \\
\text { Funding/COI }{ }^{a}\end{array}$ & $\begin{array}{c}\text { Design } \\
\text { (Mean/Median } \\
\text { Years of Follow-Up) }\end{array}$ & $n$ (Women) & $\begin{array}{c}\text { Categories of Alcohol } \\
\text { Consumption/Type of } \\
\text { Drink }\end{array}$ & Variable/s & $\begin{array}{c}\text { Reference } \\
\text { Group }(\mathrm{HR}=1)\end{array}$ & Outcomes/Conclusions ${ }^{b}$ \\
\hline $\begin{array}{l}\text { Suadicani, } 2008 \text { [61] } \\
\text { The King Christian } \\
\text { X's Foundation, The } \\
\text { Danish Medical } \\
\text { Research Council, } \\
\text { The Danish Heart } \\
\text { Foundation, and The } \\
\text { Else \& Mogens } \\
\text { Wedell Wedellsborg } \\
\text { Foundation. }\end{array}$ & $\begin{array}{c}\text { Prospective cohort } \\
\text { (16 y) }\end{array}$ & $\begin{array}{c}3022 \text { Caucasian males } \\
53-74 \text { y old }\end{array}$ & $\begin{array}{l}1 \text { SDU: } 10-12 \text { g ethanol } \\
\text { Wine, beer, and spirits }\end{array}$ & $\begin{array}{l}\text { All-cause and } \\
\text { IHD-related death } \\
\text { within the different } \\
\text { blood phenotypes }\end{array}$ & $\begin{array}{c}\text { Alcohol } \\
\text { abstainers } \\
\text { (comparison only } \\
\text { for wine } \\
\text { drinkers) }\end{array}$ & $\begin{array}{l}\text { For beer, the median }\left(\mathrm{P}_{20}, \mathrm{P}_{80}\right) \text { number } \\
\text { of drinks / week among those with the } \\
\text { non-O phenotype was significantly } \\
\text { higher in those who died (overall } \\
\text { mortality): } 10.5(0,15.5) \text { vs } 7.5(0,10.5) \text {; } \\
\qquad \leq \leq .001 . \\
\text { The effect of wine intake on all-cause } \\
\text { mortality among middle-aged and } \\
\text { elderly men may depend on ABO } \\
\text { phenotypes. Among non-O phenotype, } \\
\text { drinking } 1-8 \text { drinks/w: HR: } 0.8 \text { ( } 0.7 \text { to } \\
\text { 1.8) and drinking }>8 \text { drinks } / \text { w: HR: } 0.7 \\
(0.6 \text { to } 0.98)\end{array}$ \\
\hline
\end{tabular}

Bell et al., 2017 [49]

National Institute for

Health Research,

Welcome Trust, the

Medical Research

Council prognosis

research strategy

Partnership and

other government

health-related

agencies.
$1 \mathrm{SDU}^{\mathrm{c}}: 8 \mathrm{~g}$

Non-drinkers. Former

$$
\text { drinkers }
$$

Occasional drinkers:

drinks rarely or

occasionally. Moderate:

(6 y)

1937,360 (51\% women)

Men: 21 SDU/w or 3

SDU/day. Women: 14

SDU/w or 2 SDU/day

Heavy drinkers

Alcohol in general

Non-drinkers (former and occasional drinkers removed) had an increased risk of CV death (HR: 1.32 (1.27 to 1.38)) and all-cause mortality (HR: 1.24 (1.20 to 1.28$)$ ).

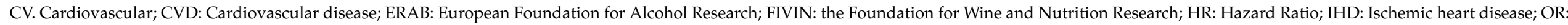

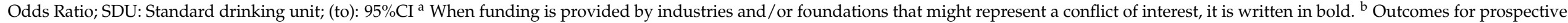

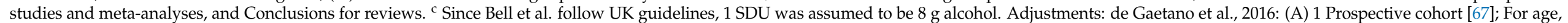

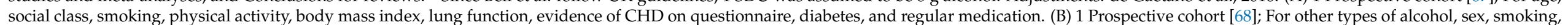

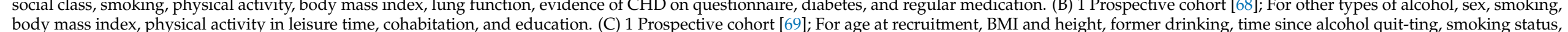

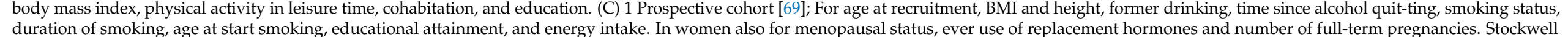

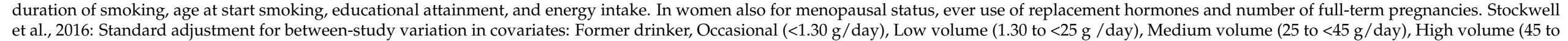

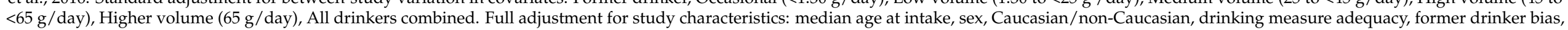

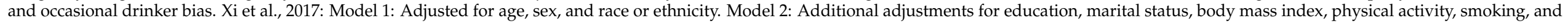
diabetes) Bell et al., 2017: HRs adjusted for age (and age 2), sex, socioeconomic deprivation, and smoking status. Suadicani, 2008: Age adjusted (only for wine drinking). 
Studies on general alcohol consumption have similar conclusions. A prospective cohort study by Suadicani et al. found an association between wine consumption and all-cause mortality, with a consistent effect at $84 \mathrm{~g}$ alcohol/week, and a larger effect seen with higher consumption in men with non-O blood type [34,61]. However, a meta-analysis by Stockwell et al. [53] suggested that, when the necessary adjustments for study design characteristics are implemented, no association of moderate alcohol consumption with mortality is observed. Two later prospective studies, with well-adjusted variables, confirmed the association between lower risk of total and CV mortality $[49,51]$ and moderate alcohol consumption defined by $168 \mathrm{~g} /$ week, $24 \mathrm{~g} /$ day for men and $112 \mathrm{~g} /$ week, $16 \mathrm{~g} /$ day for women in the Bell et al. study [49] or by 43-196 g/week for men and 43-98 g/week for women in the Xi et al. study [51].

\section{Gender Differences}

In the EPIC study, beer consumption in women was more strongly related than wine consumption to overall mortality for amounts $>21 \mathrm{~g} /$ week compared with the reference category (0.7-20.3 g/week) [69]. On the other hand, in the study by $\mathrm{Xi}$ et al., the protective effect of low and moderate alcohol consumption against all-cause and CV disease (CVD) mortality was more pronounced in women [51]. Thus, it seems that women may be both more sensitive to the protective effects against mortality of moderate beer intake and to the risk effects of higher amounts.

\section{Moderate Beer Consumption and Obesity, Diabetes, and Osteoporosis}

Table 6 details the studies on this subject. Although beer seems to have a direct effect on weight gain [52], and on waist circumference in men [59], there is not enough evidence to confirm whether moderate intake $(<500 \mathrm{~mL} /$ day $)$ is associated with general or abdominal obesity [55], although daily amounts $\geq 500 \mathrm{~mL}$ increase the risk of not losing weight [59]. In this regard, Padro et al., have reported that the moderate consumption of either alcoholic (30 g/day for men; $15 \mathrm{~g}$ /day for women) or non-alcoholic beer for four weeks did not increase the body weight of obese individuals [46]. Furthermore, moderate beer consumption was associated with increases in the anti-oxidative properties of high-density lipoprotein, which facilitate the efflux of cholesterol [46]. 
Table 6. Summary of main obesity, diabetes, and osteoporosis studies.

\begin{tabular}{|c|c|c|c|c|c|c|}
\hline $\begin{array}{c}\text { Study } \\
\text { Funding/COI }{ }^{a}\end{array}$ & $\begin{array}{l}\text { Design (Mean/Median } \\
\text { Years of Follow-Up) }\end{array}$ & $n$ (Women) & $\begin{array}{c}\text { Categories of Alcohol } \\
\text { Consumption/Type of } \\
\text { Drink }\end{array}$ & Variable/s & $\begin{array}{l}\text { Reference Group } \\
\quad(\mathrm{HR}=1)\end{array}$ & Outcomes/Conclusions ${ }^{b}$ \\
\hline $\begin{array}{l}\text { Fresan et al., } 2016 \text { [52] } \\
\text { The Spanish Ministry of } \\
\text { Health, the Navarra } \\
\text { Regional Government, and } \\
\text { the University of } \\
\text { Navarra. }\end{array}$ & $\begin{array}{l}\text { Prospective cohort } \\
\qquad(4 \mathrm{y})\end{array}$ & 15,765 adults & $\begin{array}{c}\text { Beverages groups: } \\
\text { Water, low/non-caloric } \\
\text { beverages (diet soda } \\
\text { beverages, coffee without } \\
\text { sugar), milk, juice, and } \\
\text { sugared coffee (dairy } \\
\text { products, juices, coffee with } \\
\text { sugar). } \\
\text { Occasional consumption } \\
\text { (SSSBs and spirits). Wine, } \\
\text { beer }\end{array}$ & $\begin{array}{l}\text { Change in BW and } \\
\text { new-onset obesity }\end{array}$ & No substitution & $\begin{array}{l}\text { Substitution of one beer with one serving } \\
\text { of water per day at baseline was related to } \\
\text { a lower incidence of obesity (OR 0.81, } \\
95 \% \text { CI } 0.69 \text { to } 0.94 \text { and OR } 0.84,95 \% \mathrm{CI} 0.71 \\
\text { to } 0.98 \text {, when further adjusted for the } \\
\text { consumption of other beverage groups) } \\
\text { and to higher weight loss (-328 g, } 95 \% \mathrm{CI} \\
\text { - } 566 \text { to - } 89 \text { ). }\end{array}$ \\
\hline $\begin{array}{l}\text { Bendsen et al., } 2013 \text { [55] } \\
\text { The Dutch Beer Institute } \\
\text { (funded by the Dutch } \\
\text { Brewers)/ Three of the } \\
\text { authors are employed by or } \\
\text { are board members of the } \\
\text { Dutch Beer Institute. }\end{array}$ & $\begin{array}{c}\text { Systematic review of } 35 \\
\text { observational studies and } \\
12 \text { experimental studies } \\
\text { Meta-analyses: } \\
14 \text { observational studies ( } 11 \\
\text { cross-sectional and } 3 \\
\text { prospective) included in } \\
\text { dose-response graphs. } 10 \\
\text { intervention studies ( } 6 \text { beer } \\
\text { vs non-alcoholic beer and } 4 \\
\text { beer vs control) included in } \\
\text { quantitative synthesis }\end{array}$ & & $\begin{array}{c}1 \text { SDU beer = } \\
330 \mathrm{~mL}, 4.6 \% \text { alcohol }= \\
12 \mathrm{~g} / \text { drink. } \\
/ \\
\text { Beer }\end{array}$ & $\begin{array}{c}\text { BW increase, BMI, } \\
\text { and abdominal } \\
\text { obesity (WC and } \\
\text { WHR) }\end{array}$ & $\begin{array}{l}\text { Control: } \\
\text { Non-drinkers or in } \\
\text { the absence of } \\
\text { non-drinkers, the } \\
\text { group with the } \\
\text { lowest beer intake } \\
\text { Low or } \\
\text { non-alcoholic beer }\end{array}$ & $\begin{array}{l}\text { Dose-response graphs: High beer intake } \\
\text { ( }>4 \mathrm{~L} / \mathrm{w} \text { ) was associated with a higher } \\
\text { degree of abdominal obesity in men. } \\
\text { Quantitative synthesis: High beer } \\
\text { consumption (about } 1000 \mathrm{~mL} / \text { day; } 5 \% \\
\text { alcohol) did not result in increased BW } \\
\text { compared with control groups but did } \\
\text { result in increased BW compared with low- } \\
\text { or non-alcoholic beer groups (mean } \\
\text { difference } 0.73 \mathrm{~kg}, 95 \% \text { CI: } 0.53 \text { to } 0.92 \text {; } \\
\mathrm{z}=7.39, p<0.0001, \mathrm{I} 2=0 \% \text { ) }\end{array}$ \\
\hline $\begin{array}{l}\text { Schütze et al., } 2009 \text { [59] } \\
\text { The German Cancer Aid, } \\
\text { the German Federal } \\
\text { Ministry of } \\
\text { Education and Research } \\
\text { and the European Union. }\end{array}$ & $\begin{array}{c}\text { Prospective cohort } \\
(8.5 \mathrm{y})\end{array}$ & 20,625 (12,749 women) & $\begin{array}{c}\text { WOMEN: } \\
\text { No beer. Very light: }>0 \text { to } \\
<125 \mathrm{~mL} / \text { day. Light: } \geq 125 \\
\text { to }<250 \mathrm{~mL} / \text { day. Moderate: } \\
\geq 250 \mathrm{~mL} / \mathrm{d} \\
\text { MEN: } \\
\text { No beer. Very light: }>0 \text { to } \\
<250 \mathrm{~mL} / \text { day. Light: } \geq 250 \\
\text { to }<500 \mathrm{~mL} / \text { day. Moderate: } \\
\geq 500 \text { to }<1000 \mathrm{~mL} / \text { day } \\
\text { Heavy: } \geq 1000 \mathrm{~mL} / \text { day } \\
/ \\
\text { Beer }\end{array}$ & $\begin{array}{l}\text { WC change } \\
\text { BW change }\end{array}$ & Very light & $\begin{array}{l}\text { MEN: Moderate beer consumption } \\
\text { showed significant lower relative odds for } \\
\text { WC loss (OR 0.44, } 95 \% \text { CI } 0.24 \text { to } 0.80 \text { ) } \\
\text { WOMEN: Although beer-abstaining } \\
\text { women showed significantly lower } \\
\text { relative odds (OR.0.88; CI } 0.81,0.96 \text { ) for } \\
\text { WC gain compared with their } \\
\text { very-low-level-drinking counterparts, } \\
\text { significance was lost once the model was } \\
\text { adjusted by HC change; however, the new } \\
\text { OR was on the border of significance } \\
\text { (OR.0.91; CI } 0.83,1.00 \text { ) }\end{array}$ \\
\hline
\end{tabular}


Table 6. Cont.

\begin{tabular}{|c|c|c|c|c|c|c|}
\hline $\begin{array}{c}\text { Study } \\
\text { Funding/COI a }\end{array}$ & $\begin{array}{l}\text { Design (Mean/Median } \\
\text { Years of Follow-Up) }\end{array}$ & $n$ (Women) & $\begin{array}{c}\text { Categories of Alcohol } \\
\text { Consumption/Type of } \\
\text { Drink }\end{array}$ & Variable/s & $\begin{array}{l}\text { Reference Group } \\
\quad(\mathrm{HR}=1)\end{array}$ & Outcomes/Conclusions ${ }^{b}$ \\
\hline $\begin{array}{l}\text { Padro et al., } 2018 \text { [46] } \\
\text { Fundacion Cerveza y } \\
\text { Salud, Madrid, Spain; The } \\
\text { European Foundation for } \\
\text { Alcohol Research; Spanish } \\
\text { Ministry of Economy and } \\
\text { Competitiveness of Science; } \\
\text { Institute of Health Carlos } \\
\text { III. }\end{array}$ & $\begin{array}{l}\text { Open-label, prospective } \\
\text { randomized, two-arm, } \\
\text { longitudinal cross-over }\end{array}$ & 36 (15 women) & $\begin{array}{c}\text { WOMEN: } \\
330 \mathrm{~mL} / \text { day normal or } \\
\text { non-alcoholic beer }(15 \\
\text { g/day or } 0 \text { g/day alcohol) } \\
\text { MEN: } \\
660 \mathrm{~mL} / \text { day normal or } \\
\text { non-alcoholic beer }(30 \\
\text { g/day or } 0 \mathrm{~g} / \text { day alcohol) } \\
\text { / } \\
\text { Beer }\end{array}$ & $\begin{array}{c}\text { BMI } \\
\text { T2D } \\
\text { Lipid Profile }\end{array}$ & & $\begin{array}{l}\text { Moderate beer consumption (traditional or } \\
\text { alcohol-free) does not increase body } \\
\text { weight in obese healthy individuals or } \\
\text { have negative effects on the vascular } \\
\text { system. Moderate consumption was } \\
\text { associated with reduced risk of } \\
\text { dyslipidemia, increased anti-oxidative } \\
\text { properties of high-density lipoprotein, and } \\
\text { increased efflux of cholesterol. }\end{array}$ \\
\hline $\begin{array}{l}\text { Polsky et al., } 2017 \text { [50] } \\
\text { None declared }\end{array}$ & $\begin{array}{l}\text { Systematic Review of } 96 \\
\text { studies }\end{array}$ & $\begin{array}{l}18 \text { studies included more } \\
\text { than } 10,000 \text { subjects each. }\end{array}$ & Alcohol in general & & & $\begin{array}{l}\text { Moderate alcohol consumption generally } \\
\text { reduces diabetes risk. }\end{array}$ \\
\hline $\begin{array}{l}\text { Cullman et al. } 2012 \text { [43] } \\
\text { The Swedish Research } \\
\text { Council; the Swedish } \\
\text { Diabetes Association; the } \\
\text { Swedish Council } \\
\text { of Working Life and Social } \\
\text { research; and } \\
\text { Novo Nordisk Scandinavia. }\end{array}$ & $\begin{array}{l}\text { Prospective cohort } \\
\quad(8-10 \text { y) }\end{array}$ & $\begin{array}{l}5128 \text { adults (3058 women) } \\
\text { with normal glucose } \\
\text { tolerance and } 111 \text { ( } 41 \\
\text { women) with pre-diabetes. } \\
35-56 \text { y old }\end{array}$ & $\begin{array}{c}\text { Abstainers } \\
\text { Total alcohol } \\
\text { Occasional: } 0.01-1.49 \mathrm{~g} / \text { day } \\
\text { in women, } 0.01-6.79 \mathrm{~g} / \text { day } \\
\text { in men. Low: } 1.50-4.71 \\
\text { g/day in women, } 6.80-13.01 \\
\text { g/day in men. Medium: } \\
\text { 4.72-8.75 } \mathrm{g} / \text { day in women, } \\
\text { 13.02-22.13 g/day in men. } \\
\text { High: } \geq 8.76 \mathrm{~g} / \text { day in } \\
\text { women, } \geq 22.14 \mathrm{~g} / \text { day in } \\
\text { men } \\
\text { Wine } \\
\text { Occasional: } \leq 0.32 \mathrm{~g} / \text { day in } \\
\text { women, } \leq 0.99 \mathrm{~g} / \text { day in } \\
\text { men. Medium: } 0.33-1.65 \\
\text { g/day in women, } 1-4.99 \\
\text { g/day in men. High: } \geq 1.66 \\
\text { g/day in women, } \geq 5 \mathrm{~g} / \text { day } \\
\text { in men } \\
\text { Beer (only in men) } \\
\text { Occasional: } \leq 0.99 \mathrm{~g} / \text { day. } \\
\text { Medium: } 1-4.99 \mathrm{~g} / \text { day. } \\
\text { High: } \geq 5 \mathrm{~g} / \text { day } \\
/ \\
\text { Wine, beer and spirits }\end{array}$ & $\begin{array}{c}\text { PreD } \\
\text { T2D } \\
\text { PreD + T2D }\end{array}$ & Occasional drinkers & $\begin{array}{c}\text { Normal glucose tolerance at baseline } \\
\text { MEN: High alcohol: Higher risk of preD + } \\
\text { T2D (OR 1.42, 95\% CI 1.00-2.03). High } \\
\text { beer: Higher risk of preD + T2D (OR 1.63, } \\
\text { 95\% CI 1.07-2.48) and higher risk of preD } \\
\text { (OR 1.84, 95\% CI 1.13-3.01) } \\
\text { Abstainers vs occasional wine or beer } \\
\text { drinkers: Higher risk of preD + T2D (OR } \\
\text { 2.01, 95\%CI 1.01-3.98 and OR 2.13, 95\%CI } \\
\text { 1.03-4.39, respectively). } \\
\text { WOMEN: High wine: lower risk of preD } \\
\text { (OR 0.66, 95\% CI } 0.43-0.99 \text { ) } \\
\text { Normal glucose tolerance or preD at } \\
\text { baseline } \\
\text { WOMEN: Low alcohol: Lower risk of T2D } \\
\text { (OR 0.41, 95\% 0.22-0.79). Medium wine: } \\
\text { Lower risk of T2D (OR } 0.46,95 \% \mathrm{CI} \\
0.24-0.88)\end{array}$ \\
\hline
\end{tabular}


Table 6. Cont.

\begin{tabular}{|c|c|c|c|c|c|c|}
\hline $\begin{array}{c}\text { Study } \\
\text { Funding/COI }^{a}\end{array}$ & $\begin{array}{l}\text { Design (Mean/Median } \\
\text { Years of Follow-Up) }\end{array}$ & $n$ (Women) & $\begin{array}{c}\text { Categories of Alcohol } \\
\text { Consumption/Type of } \\
\text { Drink }\end{array}$ & Variable/s & $\begin{array}{l}\text { Reference Group } \\
\quad(\mathrm{HR}=1)\end{array}$ & Outcomes/Conclusions ${ }^{b}$ \\
\hline $\begin{array}{c}\text { Yin et al., 2011 [58] } \\
\text { National Health and } \\
\text { Medical Research Council } \\
\text { of Australia, Tasmanian } \\
\text { Government and } \\
\text { Royal Hobart Hospital } \\
\text { Acute Care Programme. }\end{array}$ & $\begin{array}{l}\text { Prospective cohort } \\
\text { (2 y) }\end{array}$ & $\begin{array}{c}862 \text { (49\% women) } \\
\text { Mean age } 63 \text { y, range 51-81 }\end{array}$ & $\begin{array}{c}\text { 1SDU: } 10 \text { g alcohol } \\
\text { Frequency: } \\
\text { Never, <once a month, } 1-3 \\
\text { days/month, } 1 / 2 / 3 / 4 / 5 / 6 \\
\text { days / wk, every day. } \\
\text { Amount } \\
\text { 30mL spirits: } 1 \text { glass. } 1 \text { can } \\
\text { beer: } 2 \text { glasses. } 1 \text { bottle } \\
\text { wine }(750 \mathrm{~mL}): 6 \text { glasses. } 1 \\
\text { bottle sherry ( } 750 \mathrm{~mL}): 12 \\
\text { glasses. g/day } \\
\quad / \\
\text { Wine, beer, and spirits }\end{array}$ & BMD change & & $\begin{array}{c}\text { Total alcohol intake in men positively } \\
\text { predicted change in BMD at the lumbar } \\
\text { spine and hip (beta }=0.008 \% \text { and } 0.006 \% \\
\text { per year per gram of alcohol intake, } \\
p<0.05 \text { ). } \\
\text { The frequency of drinking red wine was } \\
\text { positively associated with percentage } \\
\text { change in BMD at the lumbar spine in men } \\
\text { (beta }=0.08 \% \text { per year per class, } p=0.048 \text { ). } \\
\text { At baseline, lumbar spine BMD was } \\
\text { positively associated with frequency of } \\
\text { low-alcohol beer drinking in women } \\
\text { (beta }=0.034 \mathrm{~g} / \mathrm{cm}(2) \text { per category, } \\
p=0.002 \text { ). }\end{array}$ \\
\hline $\begin{array}{l}\text { Mukamal et al., } 2007 \text { [62] } \\
\text { The National Heart, Lung, } \\
\text { and Blood Institute. The } \\
\text { National Institute on } \\
\text { Ageing. }\end{array}$ & $\begin{array}{c}\text { Prospective } \\
\text { population-based cohort } \\
\text { study } \\
\text { (12 y If no hip fracture } \\
7.5 \text { y If hip fracture) }\end{array}$ & $\begin{array}{l}5865 \\
\geq 60 y\end{array}$ & $\begin{array}{c}1 \text { SDU: 12-ounce can or } \\
\text { bottle of beer, } 6 \text {-ounce glass } \\
\text { of wine, and } 1 \text { shot of liquor. } \\
1 \text { SDU }=14 \mathrm{~g} \\
\text { Categories } \\
\text { Long-term abstainers, } \\
\text { former drinkers, }<1 \\
\text { drink } / \mathrm{w}, 1-6 \text { drinks } / \mathrm{w}, \\
7-13 \text { drinks } / \mathrm{w}, \geq 14 \\
\text { drinks } / \mathrm{w} \\
/ \\
\text { Wine, beer, and spirits }\end{array}$ & $\begin{array}{l}\text { Hip fracture } \\
\text { BMD }\end{array}$ & $\begin{array}{l}\text { Long-term } \\
\text { abstainers }\end{array}$ & $\begin{array}{l}\text { Strong, graded, positive relationship } \\
\text { between greater alcohol consumption and } \\
\text { greater BMD up to } 13 \text { drinks / week. } \\
\text { U-shaped relationship between alcohol } \\
\text { intake and risk for hip fracture (quadratic } \\
\text { trend: } p=0.02 \text { ), with lower HRs in } \\
\text { intermediate drinking categories. } \\
\text { Drinking }<1 \text { beer/w showed a } \\
\text { significantly lower risk of hip fracture (HR } \\
0.66,95 \% \text { CI } 0.44-0.99 \text { ). }\end{array}$ \\
\hline
\end{tabular}

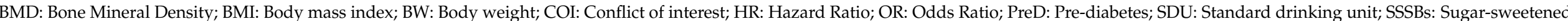

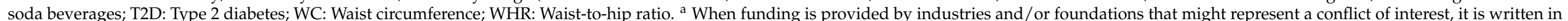

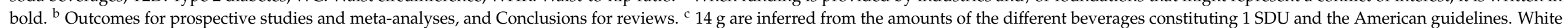

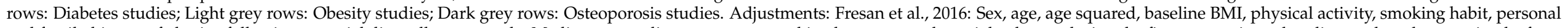

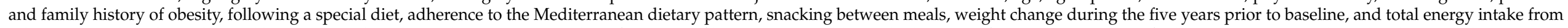

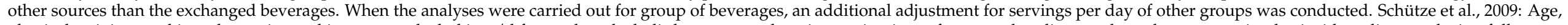

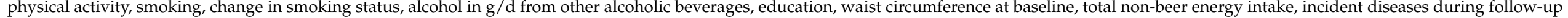

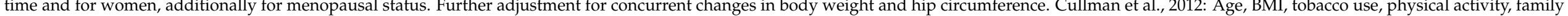

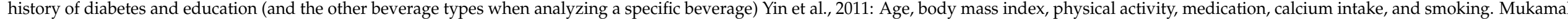

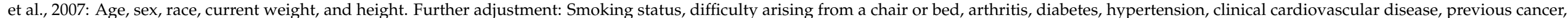
weight in early teens, leisure-time physical activity, visual problems, MMSE score, and use of estrogens, thiazide-type diuretics, and thyroid agents. 
Based on the reviewed diabetes studies $[43,50]$, moderate alcohol consumption may decrease diabetes risk in men. A meta-analysis of 13 prospective studies, with 397,296 participants, showed that wine consumption was associated with a significant reduction of the risk for type 2 diabetes mellitus (T2DM), with a pooled relative risk of 0.85 , whereas beer or spirits consumption led to a slight trend towards a decreasing risk for T2DM (relative risk 0.96 and 0.95 , respectively) [70]. Chronic alcohol consumption, however, is considered a risk factor for T2DM, which may be triggered by a deterioration in glucose tolerance, alterations in signalling of peptides involved in appetite regulation, and dysfunction and apoptosis of pancreatic $\beta$-cells [71,72].

Data on bone mineral density (BMD) and fracture risk have been less conclusive, probably due to the few studies available, and both relatively high and low levels of alcohol consumption have shown benefits for bone health. Thus, the consumption of both beer and wine at doses up to $60 \mathrm{~g} /$ day in men alone in the study by Yin et al. [58], and up to 13 drinks/week (182 g/week) in the study by Mukamal et al. [62], were shown to increase $\mathrm{BMD}$ and/or decrease risk of fracture in the elderly. Even very low levels of consumption were associated with a decreased fracture risk. Considering beer specifically, consumption of $<1$ beer/week ( $<14 \mathrm{~g} /$ week) in men and women was significantly associated with a lower risk of hip fracture (HR 0.66, 95\%CI 0.44-0.99) [62]. Notably, low-alcohol beer consumption in women was associated with increased lumbar BMD [58], suggesting that, beyond the putative positive effect of alcohol on BMD, the non-alcoholic components of beer may also be involved. Other compounds present in beer (e.g., phytoestrogens such as 8-prenylnaringenin) act synergically with silicon to stimulate osteoblast cells, improve bone structure, and help remineralize bone and teeth [44]. The polyphenolic fraction, flavonoids, and the silicon content in beer may contribute to the positive effects on bone metabolism [45]. The protective effect of polyphenols has also been proven in human studies, where they reduced systolic and diastolic pressure and reduced lipoprotein cholesterol serum levels, among others [73]. The cardioprotective role of polyphenols in beer (traditional or alcohol-free) in particular has been reported in individuals with high cardiovascular risk $[8,74]$.

\section{Gender Differences}

With regard to obesity, the study by Schütze et al. [59] suggested that only men observe a risk for an increase in waist circumference (WC) with beer consumption of $>500 \mathrm{~mL} /$ day. In women, beer-abstainers showed lower relative odds for WC gain compared with their very low-level drinking counterparts ( 1 to $<125 \mathrm{~mL} /$ day), which was close to significance.

Similar gender differences were seen in the diabetes studies. Cullman et al. found that alcohol effect on glucose metabolism was different between men and women [43], depending on amounts of consumption and alcohol type; overall, in individuals with normal glucose tolerance, a decrease in T2DM risk was observed in occasional consumers of beer and wine vs abstainers among men, and in high consumers ( $\geq 192 \mathrm{~g} /$ week) of wine vs occasional consumers among women. This cohort study showed that men who were high consumers of beer and had baseline normal glucose tolerance had a significantly increased risk of developing abnormal glucose regulation (OR 1.63, CI 1.07-2.48 for pre-diabetes plus T2DM and OR 1.84, CI 1.13-3.01 for pre-diabetes) compared to occasional drinkers [43]. Men abstainers had a significantly higher risk of developing abnormal glucose regulation (OR 2.13, CI 1.03-4.39) than occasional beer drinkers, suggesting occasional beer consumption may be protective in men. Data for beer consumption in women were not provided in the Cullman et al. study. When considering individuals with normal glucose tolerance or pre-diabetes at baseline, the only significant difference found when using occasional drinking as a reference was the case of women with low consumption of total alcohol, who showed a decreased risk of T2DM (OR 0.41, CI 0.22-0.79). Most studies reviewed by Polsky et al. [50] also showed differences between men and women. In one study, a lower risk for T2DM was only observed in women who consumed alcohol (any quantity; no dose-relationship observed) compared to lifetime abstainers, but this was not found 
in men [75]. Another study showed that in men alone, a moderate alcohol consumption (10-14.9 g/day) was associated with a reduced risk of T2DM with respect to very low consumption (0.01-4.9 g/day), linked to wine consumption [76].

Regarding BMD, the study by Yin et al. [58] found that alcohol intake was positively associated only in men with an increase in the percentage of spinal and hip BMD after two years, whereas in women, lumbar spine BMD at baseline was positively associated with frequency of low-alcohol beer consumption (beta $=0.034 \mathrm{~g} / \mathrm{cm}^{2}$ per category, $p=0.002$ ).

\section{Discussion}

Despite the paucity of studies specifically exploring beer-related health effects, available data suggest that moderate beer consumption is associated with a decreased risk for non-fatal CV events and total mortality. For other health effects, such as those on general or abdominal obesity, study data have generally been inconclusive, although a recent small study suggests that moderate consumption of either alcoholic or non-alcoholic beer does not increase body weight in obese individuals [46]. Furthermore, moderate beer consumption has been associated with decreased diabetes risk (only in men), and with an increase in BMD, which lowers the risk of fracture in the elderly.

Although the available evidence supports the health benefits of moderate beer consumption in adults (aged $\geq 18$ years), study heterogeneity makes it difficult to establish the precise quantity of beer needed to obtain these benefits. Different units of measurement (i.e., grams of alcohol or non-standardized drinks per day vs. standard drink units), and different definitions of consumption levels limit the direct comparison of these studies. Nevertheless, given the ranges of alcohol consumption associated with observed benefits in CVD (40-252 g/week for men; 21-210 g/week for women), mortality (75-196 g/week for men; 75-112 g/week for women), and diabetes, obesity, and osteoporosis (12-350 g/week for men; $12-210 \mathrm{~g} /$ week for women), a conservative upper limit of moderate beer drinking in men could be $\leq 196 \mathrm{~g}$ /week (approximately 1-2 beers per day). Available studies suggest that women may present a higher sensitivity to beer effects and, therefore, their upper limit of moderate consumption may be slightly lower at $\leq 112 \mathrm{~g} /$ week (approximately 1 beer per day). Notably, these values are similar to the low-risk drinking guidelines established by many countries (Table 1) [1-6]. Importantly, evaluating the overall effect of alcohol consumption on health is challenging, given it can be linked to improved benefits in CVD, as shown in this study, but it can also be associated with an increased risk of cancer [77]. Notably, moderate alcohol consumption varies between reports, and large-scale studies are warranted to adequately evaluate the role that specific ranges of alcohol consumption play in health.

Aside from gender differences, alcohol-associated health benefits might be modulated by intrinsic characteristics of populations, including their socioeconomic status [68] and/or diet and general lifestyle. In a well-established example, the Mediterranean diethistorically associated with high life expectancy and low CVD rates-is characterized by its high consumption of fresh foods, low consumption of animal fats, and low-to-moderate consumption of wine, generally with meals [78]. Indeed, the food pyramid recommended by the Spanish Society of Community Nutrition reflects the Mediterranean diet and includes fermented alcoholic beverages (wine, beer, and cider) among foods and drinks advised for an optional, occasional, and moderate consumption [3]. Importantly, this inclusion of alcoholic beverages in the food pyramid regards its consumption with meals, not alone. The inclusion of optional alcohol in the food pyramid is in agreement with data that shows that daily moderate beer consumption in the context of a Mediterranean diet is associated with favourable changes in the blood lipid profile [24].

The moderate consumption of alcohol $\leq 196 \mathrm{~g} /$ week ( $\leq 28 \mathrm{~g}$ /day or $1-2$ beers daily) or $\leq 112 \mathrm{~g}$ /week ( $\leq 16 \mathrm{~g} /$ day or 1 beer daily) for men and women, respectively, has been associated with a variety of health benefits. However, it must be noted that weekly recommended amounts of alcohol should be spread across several days and not include episodes of heavy alcohol use or "binge drinking", as irregular heavy drinking is associated with a 
higher risk of ischemic heart disease [79]. This episodic heavy drinking is defined by the World Health Organization as consumption of $\geq 60 \mathrm{~g}$ (approximately $\geq 6$ drinks) per occasion [80] and by the United States National Institute on Alcohol Abuse and Alcoholism [81] as consumption of $\geq 5$ drinks (male) or $\geq 4$ drinks (female) in less than $2 \mathrm{~h}$. While moderate regular drinking is associated with a lower risk of ischemic heart disease compared with abstention [54,82], excessive or binge drinking not only increases the risk of CV events, but also the risk of all-cause mortality [51,83]. Therefore, consumption of moderate amounts of alcohol should be always considered in the context of the Mediterranean lifestyle (moderate quantities of alcohol consumed as part of a meal), as a strategy to promote a more socially responsible consumption, avoiding excessive alcohol intake, often associated with Nordic European, as well as Central and Eastern Europeans and Anglo-Saxon alcohol consumers $[10,84]$. In a recent study using data from 123,219 men and women who were followed up to 34 years of age, the authors reported that the adherence of the participants to five low-risk lifestyle-related factors (never smoking, normal weight, regular physical activity, healthy diet, and moderate alcohol consumption) could prolong life expectancy at age 50 years by 14.0 and 12.2 years for female and male US adults, respectively, compared with individuals who adopted no low-risk lifestyle factors [85].

In developing this review, we considered the possibility that study sponsors might bias published results. Reported funding sources and conflict of interests (COIs) were assessed for every study selected for this review. Out of the selected studies, only three were directly funded by alcohol-related foundations [34,55,57], and COIs were reported by some of their authors. In addition, the sponsors of these three studies declared no intervention in the study execution and writing, and no differences in study results were observed regardless of funding source.

In conclusion, we consider that an approximate intake of 10-16 $\mathrm{g}$ alcohol/day ( 1 beer/day) for women and 20-28 g alcohol/day (1-2 beers/day) for men could be defined as moderate beer drinking, providing that the consumption is distributed throughout the week with no heavy episodic or "binge drinking" on a single occasion, especially during weekends. Moderate beer drinking decreases CV risk and overall mortality. In addition, moderate consumption decreases diabetes risk in men, increases BMD, lowering the risk of fracture in the elderly, and does not seem to be associated with general or abdominal obesity. Furthermore, moderate beer drinking should be considered within the context of mealtime consumption, as the custom in Mediterranean countries. Future studies should refine the quantity of beer considered as low-to-moderate consumption, which is the lowest risk level, and further determine the possible health benefits associated with moderate beer drinking.

Although research in this field is acquiring great interest and possible benefits are being found, the authors of this article insist on not recommending the consumption of alcohol in children, adolescents, pregnant women, adults under medication, or at work when using machinery (or driving). In addition, the consumption of alcohol must be always accompanied by meals and excess must be avoided.

Author Contributions: Conceptualization, methodology and writing-review: A.M., L.S.-M., F.P.-J., V.P., F.J.T. and R.E. All authors have read and agreed to the published version of the manuscript.

Funding: This study was partially supported by the "Centro de Información Cerveza y Salud". The funding organization has not had any role in the data collection, their analysis and interpretation, nor in the right to approve or disapprove publication of the finished manuscript.

Institutional Review Board Statement: Not applicable.

Informed Consent Statement: Not applicable.

Data Availability Statement: No new data were created or analyzed in this study. Data sharing is not applicable to this article.

Acknowledgments: We thank Almudena Pardo-Mateos who provided professional writing services. 
Conflicts of Interest: R.E. reports grants from Spanish Institute of Health "Carlos III" (Spain), Cerveza y Salud (Spain), Fundación Dieta Mediterranea (Spain), and grants from Bicentury SA (Spain), Grand Fountaine (Spain), Novartis SA (Spain), and Uriach Laboratories (Spain). He is also a member of the Cerveza y Salud Scientific Committee. Further, personal fees for given lectures from Brewers of Europe (Belgium), Fundacion Cerveza y Salud (Spain), Pernaud-Ricard (Mexico), Instituto Cervantes (Alburquerque, USA), Instituto Cervantes (Milan, Italy), Instituto Cervantes (Tokyo, Japan), Lilly Laboratories (Spain), Prodeca-Generalitat de Catalunya (Spain), Wine and Culinary International, International Forum (Spain), and non-financial support from Harvard School of Public Health (Boston, USA), Columbia University (NYC, USA), ERAB (Belgium), Fundació Clinic (Spain), and Fundació Bosch i Gimpera (Spain). A.M. reports having received research funding from the Cerveza y Salud Information Centre, the Spanish arm of European Brewers Association, and being a member of the Cerveza y Salud Scientific Committee. F.J.T. reports having received speaker's bureau and consultant/advisory board fees from Cerveza y Salud, AstraZeneca, Amgen, Boehringer Ingelheim, Bristol-Myers Squibb, Eli Lilly and Company, GlaxoSmithKline, Janssen Pharmaceuticals, Merck Sharpe \& Dohme, Novartis Pharmaceuticals Co., Novo Nordisk, Sanofi, and Regeneron Pharmaceuticals, L.S.-M., V.P., F.J.P.-J. declare not to have competing interests.

\section{References}

1. Kalinowski, A.; Humphreys, K. Governmental Standard Drink Definitions and Low-Risk Alcohol Consumption Guidelines in 37 Countries. Addiction 2016, 111, 1293-1298. [CrossRef]

2. Arbesu, J.A.; Armenteros del Olmo, L.; Casquero, R.; Goncalves, F.; Guardia Serecigni, J.; López Santiago, A.; Pascual Pastor, F.; Represas Carrera, F.J.; Sala Añó, C. Manual de Consenso Sobre Alcohol En Atención Primaria; Socidrogalcohol: Barcelona, Spain, 2016.

3. Aranceta-Bartrina, J.; Partearroyo, T.; López-Sobaler, A.M.; Ortega, R.M.; Varela-Moreiras, G.; Serra-Majem, L.; Pérez-Rodrigo, C. Updating the Food-Based Dietary Guidelines for the Spanish Population: The Spanish Society of Community Nutrition (Senc) Proposal. Nutrients 2019, 11, 2675. [CrossRef]

4. Department of Health. UK Chief Medical Officers' Low Risk Drinking Guidelines; Department of Health: London, UK, 2016.

5. U.S. Department of Health and Human Services. 2015-2020 Dietary Guidelines for Americans, 8th ed.; U.S. Department of Health and Human Services: Washington, DC, USA, 2015.

6. Canadian Centre on Substance Use and Adiction. Alcohol Drinking Guidelines; Canadian Centre on Substance Use and Adiction: Ottawa, ON, Canada, 2018.

7. Arranz, S.; Chiva-Blanch, G.; Valderas-Martínez, P.; Medina-Remón, A.; Lamuela-Raventós, R.M.; Estruch, R. Wine, Beer, Alcohol and Polyphenols on Cardiovascular Disease and Cancer. Nutrients 2012, 4, 759-781. [CrossRef]

8. Chiva-Blanch, G.; Magraner, E.; Condines, X.; Valderas-Martínez, P.; Roth, I.; Arranz, S.; Casas, R.; Navarro, M.; Hervas, A.; Sisó, A.; et al. Effects of Alcohol and Polyphenols from Beer on Atherosclerotic Biomarkers in High Cardiovascular Risk Men: A Randomized Feeding Trial. Nutr. Metab. Cardiovasc. Dis. 2015, 25, 36-45. [CrossRef]

9. The Brewers of Europe. European Beer Trends-Statistics Report | 2019 Edition; The Brewers of Europe: Brussels, Belgium, 2020.

10. Shield, K.D.; Rylett, M.; Rehm, J. Public Health Gains and Missed Opportunities. Trends in Alcohol Consumption and Attributable Mortality in the WHO European Region, 1990-2014: A Report to the WHO European Region; Centre for Addiction and Mental Health: Toronto, ON, Canada, 2016; ISBN 9781771143684.

11. Missbach, B.; Majchrzak, D.; Sulzner, R.; Wansink, B.; Reichel, M.; Koenig, J. Exploring the Flavor Life Cycle of Beers with Varying Alcohol Content. Food Sci. Nutr. 2017, 5, 889-895. [CrossRef] [PubMed]

12. Sohrabvandi, S.; Mortazavian, A.M.; Rezaei, K. Health-Related Aspects of Beer: A Review. Int. J. Food Prop. 2012, 15, 350-373. [CrossRef]

13. Romeo, J.; Díaz, L.; González-Gross, M.; Wärnberg, J.; Marcos, A. Contribución a La Ingesta de Macro y Micronutrientes Que Ejerce Un Consumo Moderado de Cerveza. Nutr. Hosp. 2006, 21, 84-91. [PubMed]

14. Hill, S.T.; Sudarsanam, R.; Henning, J.; Hendrix, D. HopBase: A Unified Resource for Humulus Genomics. Database J. Biol. Databases Curation 2017, 2017, bax009. [CrossRef] [PubMed]

15. Carvalho, D.O.; Curto, A.F.; Guido, L.F. Determination of Phenolic Content in Different Barley Varieties and Corresponding Malts by Liquid Chromatography-Diode Array Detection-Electrospray Ionization Tandem Mass Spectrometry. Antioxidants 2015, 4, 563-576. [CrossRef]

16. Řehová, L.; Škeř́kova, V.; Jandera, P. Optimisation of Gradient HPLC Analysis of Phenolic Compounds and Flavonoids in Beer Using a CoulArray Detector. J. Sep. Sci. 2004, 27, 1345-1359. [CrossRef]

17. Gerhäuser, C. Beer Constituents as Potential Cancer Chemopreventive Agents. Eur. J. Cancer 2005, 41, 1941-1954. [CrossRef] [PubMed]

18. Liu, M.; Hansen, P.E.; Wang, G.; Qiu, L.; Dong, J.; Yin, H.; Qian, Z.; Yang, M.; Miao, J. Pharmacological Profile of Xanthohumol, a Prenylated Flavonoid from Hops (Humulus Lupulus). Molecules 2015, 20, 754-779. [CrossRef] [PubMed]

19. Xin, G.; Wei, Z.; Ji, C.; Zheng, H.; Gu, J.; Ma, L.; Huang, W.; Morris-Natschke, S.L.; Yeh, J.L.; Zhang, R.; et al. Xanthohumol Isolated from Humulus Lupulus Prevents Thrombosis without Increased Bleeding Risk by Inhibiting Platelet Activation and MtDNA Release. Free Radic. Biol. Med. 2017, 108, 247-257. [CrossRef] 
20. Wunderlich, S.; Zürcher, A.; Back, W. Enrichment of Xanthohumol in the Brewing Process. Mol. Nutr. Food Res. 2005, 49, 874-881. [CrossRef] [PubMed]

21. Humia, B.V.; Santos, K.S.; Barbosa, A.M.; Sawata, M.; Mendonça, M.d.C.; Padilha, F.F. Beer Molecules and Its Sensory and Biological Properties: A Review. Molecules 2019, 24, 1568. [CrossRef] [PubMed]

22. Sacanella Anglés, I.; Casas Rodriguez, R.; Viñas Esmel, E.; Castro Barquero, S.; Sacanella Meseguer, E. Prevención de La Enfermedad Cardiovascular y Bebidas Alcohólicas Fermentadas. ¿Realidad o Ficción? Nutr. Hosp. 2019, 36, 58-62.

23. Williamson, G.; Manach, C. Bioavailability and Bioefficacy of Polyphenols in Humans. II. Review of 93 Intervention Studies. Am. J. Clin. Nutr. 2005, 81, 243S-255S. [CrossRef] [PubMed]

24. Romeo, J.; González-Gross, M.; Wärnberg, J.; Díaz, L.E.; Marcos, A. Effects of Moderate Beer Consumption on Blood Lipid Profile in Healthy Spanish Adults. Nutr. Metab. Cardiovasc. Dis. 2008, 18, 365-372. [CrossRef]

25. Nishiwaki, M.; Kora, N.; Matsumoto, N. Ingesting a Small Amount of Beer Reduces Arterial Stiffness in Healthy Humans. Physiol. Rep. 2017, 5, 1-9. [CrossRef]

26. Rimm, E.B.; Williams, P.; Fosher, K.; Criqui, M.; Stampfer, M.J. Moderate Alcohol Intake and Lower Risk of Coronary Heart Disease: Meta-Analysis of Effects on Lipids and Haemostatic Factors. Br. Med. J. 1999, 319, 1523-1528. [CrossRef]

27. Di Castelnuovo, A.; Costanzo, S.; di Giuseppe, R.; de Gaetano, G.; Iacoviello, L. Alcohol Consumption and Cardiovascular Risk: Mechanisms of Action and Epidemiologic Perspectives. Future Cardiol. 2009, 5, 467-477. [CrossRef]

28. Piano, M.R. Alcohol's Effects on the Cardiovascular System. Alcohol Res. Curr. Rev. 2017, 38, $219-241$.

29. Hätönen, K.A.; Virtamo, J.; Eriksson, J.G.; Perälä, M.M.; Sinkko, H.K.; Leiviskä, J.; Valsta, L.M. Modifying Effects of Alcohol on the Postprandial Glucose and Insulin Responses in Healthy Subjects. Am. J. Clin. Nutr. 2012, 96, 44-49. [CrossRef]

30. Traversy, G.; Chaput, J.P. Alcohol Consumption and Obesity: An Update. Curr. Obes. Rep. 2015, 4, 122-130. [CrossRef]

31. Block, G. Foods Contributing to Energy Intake in the US: Data from NHANES III and NHANES 1999-2000. J. Food Compos. Anal. 2004, 17, 439-447. [CrossRef]

32. Roe, M.; Pinchen, H.; Church, S.; Finglas, P. McCance and Widdowson's The Composition of Foods Seventh Summary Edition and Updated Composition of Foods Integrated Dataset. Nutr. Bull. 2015, 40, 36-39. [CrossRef]

33. Tujague, J.; Kerr, W.C. Energy Intake Estimates of Respondent-Measured Alcoholic Beverages. Alcohol Alcohol. $2009,44,34-41$. [CrossRef] [PubMed]

34. De Gaetano, G.; Costanzo, S.; di Castelnuovo, A.; Badimon, L.; Bejko, D.; Alkerwi, A.; Chiva-Blanch, G.; Estruch, R.; la Vecchia, C.; Panico, S.; et al. Effects of Moderate Beer Consumption on Health and Disease: A Consensus Document. Nutr. Metab. Cardiovasc. Dis. 2016, 26, 443-467. [CrossRef]

35. Kawano, Y. Physio-Pathological Effects of Alcohol on the Cardiovascular System: Its Role in Hypertension and Cardiovascular Disease. Hypertens. Res. 2010, 33, 181-191. [CrossRef] [PubMed]

36. Gardner, J.D.; Mouton, A.J. Alcohol Effects on Cardiac Function. Compr. Physiol. 2015, 5, 791-802. [CrossRef] [PubMed]

37. Shi, L.; Shu, X.O.; Li, H.; Cai, H.; Liu, Q.; Zheng, W.; Xiang, Y.B.; Villegas, R. Physical Activity, Smoking, and Alcohol Consumption in Association with Incidence of Type 2 Diabetes among Middle-Aged and Elderly Chinese Men. PLoS ONE 2013, 8, e7791. [CrossRef]

38. Sato, K.K.; Hayashi, T.; Harita, N.; Koh, H.; Maeda, I.; Endo, G.; Nakamura, Y.; Kambe, H.; Kiyotaki, C. Relationship between Drinking Patterns and the Risk of Type 2 Diabetes: The Kansai Healthcare Study. J. Epidemiol. Community Health 2012, 66, 507-511. [CrossRef]

39. Marques-Vidal, P.; Vollenweider, P.; Waeber, G. Alcohol Consumption and Incidence of Type 2 Diabetes. Results from the CoLaus Study. Nutr. Metab. Cardiovasc. Dis. 2015, 25, 75-84. [CrossRef]

40. Wei, M.; Gibbons, L.W.; Mitchell, T.L.; Kampert, J.B.; Blair, S.N. Alcohol Intake and Incidence of Type 2. Diabetes Care 2000, 23, 18-24. [CrossRef] [PubMed]

41. Wannamethee, S.G.; Shaper, A.G.; Perry, I.J.; Alberti, K.G.M.M. Alcohol Consumption and the Incidence of Type II Diabetes. J. Epidemiol. Community Health 2002, 56, 542-548. [CrossRef] [PubMed]

42. Athyros, V.G.; Liberopoulos, E.N.; Mikhailidis, D.P.; Papageorgiou, A.A.; Ganotakis, E.S.; Tziomalos, K.; Kakafika, A.I.; Karagiannis, A.; Lambropoulos, S.; Elisaf, M. Association of Drinking Pattern and Alcohol Beverage Type with the Prevalence of Metabolic Syndrome, Diabetes, Coronary Heart Disease, Stroke, and Peripheral Arterial Disease in a Mediterranean Cohort. Angiology 2008, 58, 689-697. [CrossRef] [PubMed]

43. Cullmann, M.; Hilding, A.; Östenson, C.G. Alcohol Consumption and Risk of Pre-Diabetes and Type 2 Diabetes Development in a Swedish Population. Diabet. Med. 2012, 29, 441-452. [CrossRef]

44. Osorio-Paz, I.; Brunauer, R.; Alavez, S. Beer and Its Non-Alcoholic Compounds in Health and Disease. Crit. Rev. Food Sci. Nutr. 2019, 60, 1-14. [CrossRef]

45. Redondo, N.; Nova, E.; Díaz-Prieto, L.E.; Marcos, A. Effects of Moderate Beer Consumption on Health. Nutr. Hosp. 2018, 35, 41-44. [CrossRef]

46. Padro, T.; Muñoz-García, N.; Vilahur, G.; Chagas, P.; Deyà, A.; Antonijoan, R.M.; Badimon, L. Moderate Beer Intake and Cardiovascular Health in Overweight Individuals. Nutrients 2018, 10, 1237. [CrossRef] [PubMed]

47. Wood, A.M.; Kaptoge, S.; Butterworth, A.; Nietert, P.J.; Warnakula, S.; Bolton, T.; Paige, E.; Paul, D.S.; Sweeting, M.; Burgess, S.; et al. Risk Thresholds for Alcohol Consumption: Combined Analysis of Individual-Participant Data for 599912 Current Drinkers in 83 Prospective Studies. Lancet 2018, 391, 1513-1523. [CrossRef] 
48. Toma, A.; Paré, G.; Leong, D.P. Alcohol and Cardiovascular Disease: How Much Is Too Much? Curr. Atheroscler. Rep. 2017, 19, 1-7. [CrossRef] [PubMed]

49. Bell, S.; Daskalopoulou, M.; Rapsomaniki, E.; George, J.; Britton, A.; Bobak, M.; Casas, J.P.; Dale, C.E.; Denaxas, S.; Shah, A.D.; et al. Association between Clinically Recorded Alcohol Consumption and Initial Presentation of 12 Cardiovascular Diseases: Population Based Cohort Study Using Linked Health Records. BMJ 2017, 356, 1-7. [CrossRef] [PubMed]

50. Polsky, S.; Akturk, H.K. Alcohol Consumption, Diabetes Risk, and Cardiovascular Disease Within Diabetes. Curr. Diabetes Rep. 2017, 17, 136. [CrossRef] [PubMed]

51. Xi, B.; Veeranki, S.P.; Zhao, M.; Ma, C.; Yan, Y.; Mi, J. Relationship of Alcohol Consumption to All-Cause, Cardiovascular, and Cancer-Related Mortality in U.S. Adults. J. Am. Coll. Cardiol. 2017, 70, 913-922. [CrossRef] [PubMed]

52. Fresán, U.; Gea, A.; Bes-Rastrollo, M.; Ruiz-Canela, M.; Martínez-Gonzalez, M.A. Substitution Models of Water for Other Beverages, and the Incidence of Obesity and Weight Gain in the SUN Cohort. Nutrients 2016, 8, 688. [CrossRef]

53. Stockwell, T.; Zhao, J.; Panwar, S.; Roemer, A.; Naimi, T.; Chikritzhs, T. Do "Moderate" Drinkers Have Reduced Mortality Risk? A Systematic Review and Meta-Analysis of Alcohol Consumption and All-Cause Mortality. J. Stud. Alcohol Drugs 2016, 77, 185-198. [CrossRef]

54. Roerecke, M.; Rehm, J. Alcohol Consumption, Drinking Patterns, and Ischemic Heart Disease: A Narrative Review of MetaAnalyses and a Systematic Review and Meta-Analysis of the Impact of Heavy Drinking Occasions on Risk for Moderate Drinkers. BMC Med. 2014, 12, 1-11. [CrossRef]

55. Bendsen, N.T.; Christensen, R.; Bartels, E.M.; Kok, F.J.; Sierksma, A.; Raben, A.; Astrup, A. Is Beer Consumption Related to Measures of Abdominal and General Obesity? A Systematic Review and Meta-Analysis. Nutr. Rev. 2013, 71, 67-87. [CrossRef]

56. Roerecke, M.; Rehm, J. The Cardioprotective Association of Average Alcohol Consumption and Ischaemic Heart Disease: A Systematic Review and Meta-Analysis. Addiction 2012, 107, 1246-1260. [CrossRef] [PubMed]

57. Costanzo, S.; di Castelnuovo, A.; Donati, M.B.; Iacoviello, L.; de Gaetano, G. Wine, Beer or Spirit Drinking in Relation to Fatal and Non-Fatal Cardiovascular Events: A Meta-Analysis. Eur. J. Epidemiol. 2011, 26, 833-850. [CrossRef]

58. Yin, J.; Winzenberg, T.; Quinn, S.; Giles, G.; Jones, G. Beverage-Specific Alcohol Intake and Bone Loss in Older Men and Women: A Longitudinal Study. Eur. J. Clin. Nutr. 2011, 65, 526-532. [CrossRef]

59. Schütze, M.; Schulz, M.; Steffen, A.; Bergmann, M.M.; Kroke, A.; Lissner, L.; Boeing, H. Beer Consumption and the "Beer Belly": Scientific Basis or Common Belief? Eur. J. Clin. Nutr. 2009, 63, 1143-1149. [CrossRef]

60. Snow, W.M.; Murray, R.; Ekuma, O.; Tyas, S.L.; Barnes, G.E. Alcohol Use and Cardiovascular Health Outcomes: A Comparison across Age and Gender in the Winnipeg Health and Drinking Survey Cohort. Age Ageing 2009, 38, 206-212. [CrossRef]

61. Suadicani, P.; Hein, H.O.; Gyntelberg, F. Wine Intake, ABO Phenotype, and Risk of Ischemic Heart Disease and All-Cause Mortality: The Copenhagen Male Study-a 16-Year Follow-Up. Alcohol 2008, 42, 575-582. [CrossRef] [PubMed]

62. Mukamal, K.J.; Robbins, J.A.; Cauley, J.A.; Kern, L.M.; Siscovick, D.S. Alcohol Consumption, Bone Density, and Hip Fracture among Older Adults: The Cardiovascular Health Study. Osteoporos. Int. 2007, 18, 593-602. [CrossRef] [PubMed]

63. O’Donnell, M.J.; Chin, S.L.; Rangarajan, S.; Xavier, D.; Liu, L.; Zhang, H.; Rao-Melacini, P.; Zhang, X.; Pais, P.; Agapay, S.; et al. Global and Regional Effects of Potentially Modifiable Risk Factors Associated with Acute Stroke in 32 Countries (INTERSTROKE): A Case-Control Study. Lancet 2016, 388, 761-775. [CrossRef]

64. Smyth, A.; Teo, K.K.; Rangarajan, S.; O’Donnell, M.; Zhang, X.; Rana, P.; Leong, D.P.; Dagenais, G.; Seron, P.; Rosengren, A.; et al Alcohol Consumption and Cardiovascular Disease, Cancer, Injury, Admission to Hospital, and Mortality: A Prospective Cohort Study. Lancet 2015, 386, 1945-1954. [CrossRef]

65. Di Castelnuovo, A.; Costanzo, S.; Bagnardi, V.; Donati, M.B.; Iacoviello, L.; de Gaetano, G. Alcohol Dosing and Total Mortality in Men and Women: An Updated Meta-Analysis of 34 Prospective Studies. Arch. Intern. Med. 2006, 166, 2437-2445. [CrossRef]

66. Renaud, S.C.; Guéguen, R.; Siest, G.; Salamon, R. Wine, Beer, and Mortality in Middle-Aged Men from Eastern France. Arch. Intern. Med. 1999, 159, 1865-1870. [CrossRef]

67. Wannamethee, S.G.; Shaper, A.G. Type of Alcoholic Drink and Risk of Major Coronary Heart Disease Events and All-Cause Mortality. Am. J. Public Health 1999, 89, 685-690. [CrossRef] [PubMed]

68. Nielsen, N.R.; Schnohr, P.; Jensen, G.; Grønbæk, M. Is the Relationship between Type of Alcohol and Mortality Influenced by Socio-Economic Status? J. Intern. Med. 2004, 255, 280-288. [CrossRef] [PubMed]

69. Ferrari, P.; Licaj, I.; Muller, D.C.; Andersen, P.K.; Johansson, M.; Boeing, H.; Weiderpass, E.; Dossus, L.; Dartois, L.; Fagherazzi, G.; et al. Lifetime Alcohol Use and Overall and Cause-Specific Mortality in the European Prospective Investigation into Cancer and Nutrition (EPIC) Study. BMJ Open 2014, 4, e005245. [CrossRef] [PubMed]

70. Huang, J.; Wang, X.; Zhang, Y. Specific Types of Alcoholic Beverage Consumption and Risk of Type 2 Diabetes: A Systematic Review and Meta-Analysis. J. Diabetes Investig. 2017, 8, 56-68. [CrossRef]

71. Kim, J.Y.; Lee, D.Y.; Lee, Y.J.; Park, K.J.; Kim, K.H.; Kim, J.W.; Kim, W.-H. Chronic Alcohol Consumption Potentiates the Development of Diabetes through Pancreatic $\beta$-Cell Dysfunction. World J. Biol. Chem. 2015, 6, 1-15. [CrossRef] [PubMed]

72. Kim, S.J.; Kim, D.J. Alcoholism and Diabetes Mellitus. Diabetes Metab. J. 2012, 36, 108-115. [CrossRef]

73. Potì, F.; Santi, D.; Spaggiari, G.; Zimetti, F.; Zanotti, I. Polyphenol Health Effects on Cardiovascular and Neurodegenerative Disorders: A Review and Meta-Analysis. Int. J. Mol. Sci. 2019, 20, 351. [CrossRef] 
74. Chiva-Blanch, G.; Condines, X.; Magraner, E.; Roth, I.; Valderas-Martínez, P.; Arranz, S.; Casas, R.; Martínez-Huélamo, M.; Vallverdú-Queralt, A.; Quifer-Rada, P.; et al. The Non-Alcoholic Fraction of Beer Increases Stromal Cell Derived Factor 1 and the Number of Circulating Endothelial Progenitor Cells in High Cardiovascular Risk Subjects: A Randomized Clinical Trial. Atherosclerosis 2014, 233, 518-524. [CrossRef]

75. Hodge, A.M.; English, D.R.; O’Dea, K.; Giles, G.G. Alcohol Intake, Consumption Pattern and Beverage Type, and the Risk of Type 2 Diabetes. Diabet. Med. 2006, 23, 690-697. [CrossRef]

76. Rasouli, B.; Ahlbom, A.; Andersson, T.; Grill, V.; Midthjell, K.; Olsson, L.; Carlsson, S. Alcohol Consumption Is Associated with Reduced Risk of Type2 Diabetes and Autoimmune Diabetes in Adults: Results from the Nord-Trøndelag Health Study. Diabet. Med. 2013, 30, 56-64. [CrossRef]

77. Bagnardi, V.; Rota, M.; Botteri, E.; Tramacere, I.; Islami, F.; Fedirko, V.; Scotti, L.; Jenab, M.; Turati, F.; Pasquali, E.; et al. Alcohol Consumption and Site-Specific Cancer Risk: A Comprehensive Dose-Response Meta-Analysis. Br. J. Cancer 2015, 112, 580-593. [CrossRef]

78. Willett, W.C.; Sacks, F.; Trichopoulou, A.; Drescher, G.; Ferro-Luzzi, A.; Helsing, E.; Trichopoulos, D. Mediterranean Diet Pyramid: A Cultural Model for Healthy Eating. Am. J. Clin. Nutr. 1995, 6, 1402S-1406S. [CrossRef]

79. World Health Organization. Global Status Report on Alcohol and Health 2018; World Health Organization: Geneva, Switzerland, 2018.

80. National Institute on Alcohol Abuse and Alcoholism Governments Confront Drunken Violence. Bull. World Health Organ. 2010, 88, 644-645. [CrossRef] [PubMed]

81. National Institute on Alcohol Abuse and Alcoholism. NIAAA Council Approves Definition of Binge Drinking. NIAAA Newsl. 2004, 3, 3 .

82. Ruidavets, J.B.; Ducimetière, P.; Evans, A.; Montaye, M.; Haas, B.; Bingham, A.; Yarnell, J.; Amouyel, P.; Arveiler, D.; Kee, F.; et al. Patterns of Alcohol Consumption and Ischaemic Heart Disease in Culturally Divergent Countries: The Prospective Epidemiological Study of Myocardial Infarction (PRIME). BMJ 2010, 341, 1146. [CrossRef] [PubMed]

83. Horvat, P.; Stefler, D.; Murphy, M.; King, L.; McKee, M.; Bobak, M. Alcohol, Pattern of Drinking and All-Cause Mortality in Russia, Belarus and Hungary: A Retrospective Indirect Cohort Study Based on Mortality of Relatives. Addiction 2018, 113, $1252-1263$. [CrossRef] [PubMed]

84. Serra-Majem, L.; Aranceta, J. Carta al Editor. Réplica: “La Recomendación Del Consumo de Alcohol En Las ‘Guías Alimentarias Para La Población Española'. Un Mensaje Demasiado Ambiguo”. Nutr. Hosp. 2017, 34, 1006-1008. [CrossRef]

85. Li, Y.; Pan, A.; Wang, D.D.; Liu, X.; Dhana, K.; Franco, O.H.; Kaptoge, S.; di Angelantonio, E.; Stampfer, M.; Willett, W.C.; et al. Impact of Healthy Lifestyle Factors on Life Expectancies in the Us Population. Circulation 2018, 138, 345-355. [CrossRef] [PubMed] 